\title{
The Old Yellow Meeting House in Upper Freehold, New Jersey:
}

\section{An Important Historic Landmark}

\section{By Joseph W. Hammond}

\section{DOI: https://doi.org/10.14713/njs.v7i1.224}

This article establishes when the Old Yellow Meeting House was first constructed, determines when the building was enlarged and rebuilt, outlines its history in the nineteenth and twentieth centuries, and evaluates efforts in recent decades to preserve and repair this important landmark structure.

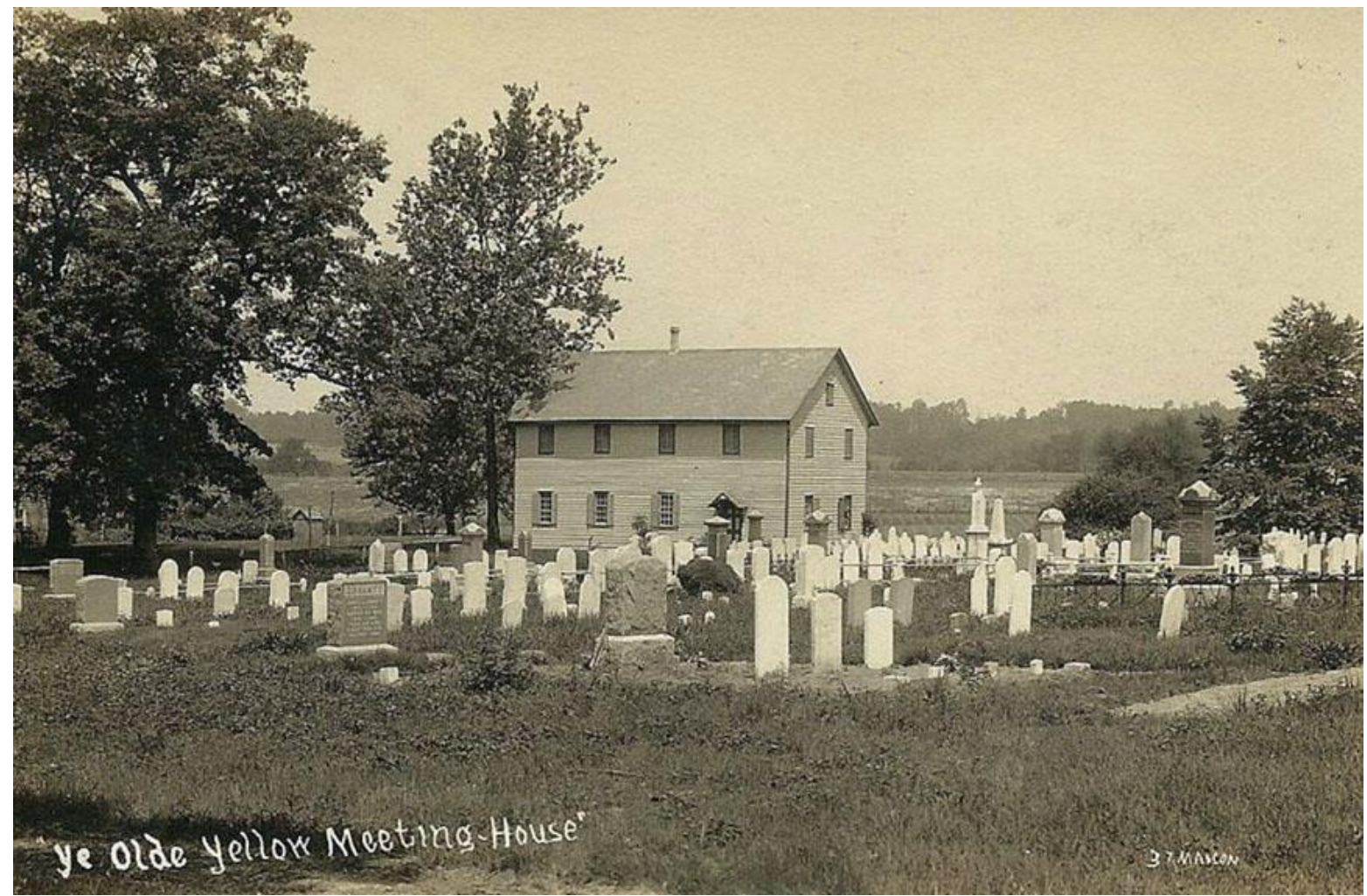

A historic view of the Old Yellow Meeting House and cemetery, taken from a photo post card ca. 1900 - 1910. It shows the building in well-kept condition, surrounded by open farmland. Courtesy The History Girl as posted on Pinterest.

One of the key historic landmarks of western Monmouth County, New Jersey, is the Old Yellow Meeting House in Upper Freehold Township, also known as the Upper Freehold Baptist 
Meeting House. ${ }^{1}$ This venerable structure sits in a picturesque graveyard, accompanied by an early parsonage. Since the nineteenth century, historians have offered a number of dates for construction of the meeting house, including 1720, 1731, 1737, and later. Recognizing the difficulty in establishing when it was first raised, a 1975 nomination form for placing the building on the New Jersey State and National Registers of Historic Places merely stated that "The extant building was probably built in the early to mid- $18^{\text {th }}$ century..."2

The year 1737 has been settled upon in recent decades as the meeting house date of construction, accepted at face value by local historians. The sole source of that information is a book published in 1792 written by the Rev. Morgan Edwards entitled Materials Towards A History of the Baptists in Jersey. In it, he stated that:

the meeting house stands in said Upperfreehold township, and county of Monmouth, 40 miles ENE from Philadelphia: the dimensions of the house are 40 feet by 30: it was built in 1737: the ground on which it stands contains about 26 acres: it was purchased from Thomas Salter: his conveyance is dated Jun. 9, 1720: the house is accommodated with a stove, and finished as usual. ${ }^{3}$

Early records of the Upper Freehold Baptist Church contain very few references to its properties. The congregation, with roots dating back to about 1706, was not formally organized until 1766. A minute book largely devoted to church admissions, dismissals, and discipline was

\footnotetext{
${ }^{1}$ The author would like to express deep gratitude to John Fabiano, a Trustee and Treasurer of the Friends of the Old Yellow Meeting House as well as Executive Director of the Monmouth County Historical Commission, for his volunteer research into the archives of the Friends and the records of the Upper Freehold Baptist Church, both of which are housed at the Allentown Public Library. Thanks are also due to Sheila Koehler, an Associate of Westfield Architects \& Preservation Consultants, for making a site visit to the meeting house on 3 August 2020, and to Philip D. Zimmerman of Lancaster, PA, a leading American furniture historian, for reading the manuscript, offering comment, and bringing the 1835 article on pulpit design to my attention. Other readers included Lee Ellen Griffith, former Director of the Monmouth County Historical Association, Gail L. Hunton, Chief of the Acquisition and Design Department of the Monmouth County Park System, Margaret Westfield, R. A., of Westfield Architects \& Preservation Consultants (who is also Vice-Chair of the New Jersey Historical Commission), and Ann Meirs Honadle Van Hise, a Friends Trustee, all of whom made helpful contributions to the preparation of this narrative.

${ }^{2}$ United States Department of the Interior, National Register of Historic Places Inventory - Nomination Form, Upper Freehold Baptist Meeting, 20 March 1975.

${ }^{3}$ Morgan Edwards, Materials Towards A History of the Baptists in Jersey (Philadelphia: Thomas Dobson, 1792), 103. The meeting house actually measured 36 feet by 26 feet.
} 
commenced in that year. It opens with a very lengthy narrative on the history of Baptists in the area up to that date. The text, however, makes no mention of when the meeting house was built. ${ }^{4}$

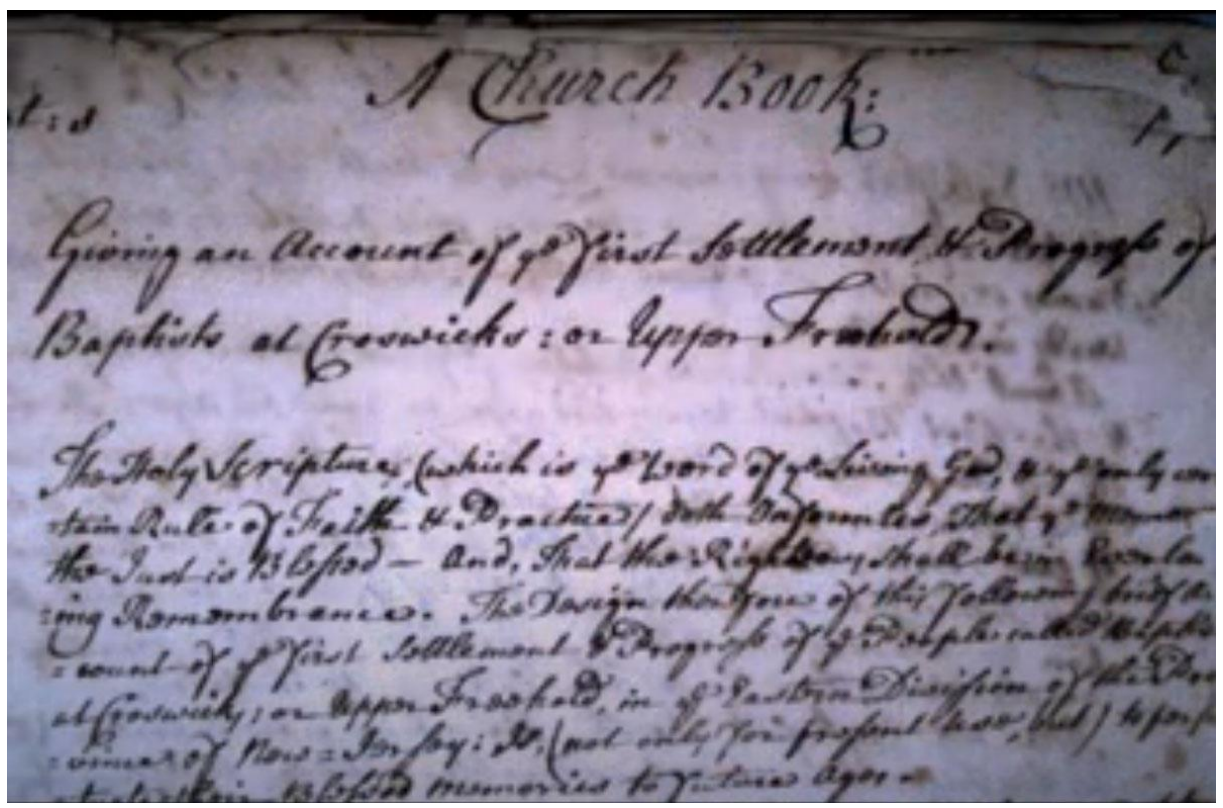

The first page of the Upper Freehold Baptist Church Book begun in 1766. Courtesy microfilm owned by Rutgers University Special Collections and University Archives.

The Rev. Morgan Edwards (1722 - 1795) of Philadelphia contemplated writing a history of the Baptist Church in each of the states that existed at that time. Only two volumes were completed and published before his death - those covering Pennsylvania and New Jersey. As a leading Baptist clergyman of his day and a principal founder of what is now Brown University in Rhode Island, he obtained access to individual congregations through the annual meetings of the Philadelphia Baptist Association, to which Upper Freehold and others in New Jersey belonged. Morgan collected by personal travel and correspondence more or less uniform information on each congregation, outlining its succession of clergymen, membership, the construction dates and sizes of meeting houses, real estate holdings, revivals, and a general historical profile. But his books are

\footnotetext{
${ }^{4}$ A typescript of the Church Book, which covers the years 1766 to 1841, can be found on the web site of the Friends of Old Yellow Meeting House at http://www.oymh.org/historical_information.html. Further references to it in this essay are cited as "Church Book Typescript."
} 
not perfect, in large measure because they were based on materials provided to him by congregational representatives. In at least one instance, his printer apparently made a typesetting error. The New Jersey volume stated that the Mount Bethel Baptist Meeting House in Somerset County was erected in 1768. Local historians in recent years had again accepted the date without question. However, a detailed study of that surviving historic landmark carried out in 2008 corrected it to $1786 .^{5}$

With that example in mind, corroborating evidence needs to be found to confirm or revise meeting house construction facts cited by Edwards. In the case of Mount Bethel, it turned out to be annual membership statistics reported to the Philadelphia Baptist Association. From 1768 to 1776 the congregation there numbered an average of 90 persons that were accommodated in a small meeting house erected in 1761. After a major spiritual revival in 1785 to 1787 , it increased to an average of 315 persons through the year 1800, a gathering that exceeded the capacity of their existing facility. So, the Baptists of Mount Bethel erected a larger house of worship in 1786 in a more central location that incorporated materials salvaged from their earlier meeting house. ${ }^{6}$

In the case of the Upper Freehold Baptists, their Church Book contains a few short references to the meeting house that help establish a general framework regarding its construction date. In 1755, a controversy arose between their minister, the Rev. John Coward, and another member of the congregation, resulting in Coward's withdrawal. The historical introduction in the Church Book relates the story:

Upon Mr. Coward's Declining the ministerial work, we seemed as Sheep without a Sheepherd [sic], to go in and out before us, consequently the meetinghouse Doors were frequently unopened on the Lord's Day, till about Septem. 1756 at which Time some of the Brethren \& wellwishers that lived compa [loss of text] together concluded to meet

\footnotetext{
${ }^{5}$ Westfield Architects \& Preservation Consultants, Historic Structure Report: Mount Bethel Baptist Meeting House (Haddon Heights, NJ: 2008), 2-7.

${ }^{6}$ Ibid, 2-6. All early records of the Mount Bethel Baptist Church were discarded about 1970, making this study a particular challenge.
} 
together on the Lord's Day, when destitute of ministerial Supply, and spend part of the Day in Praying, Reading \& Singing of Psalms, which they reduced to Practice, and so continue to this Day. ${ }^{7}$

Given this statement, a meeting house that apparently existed by 1755 was frequently closed for about a year. Another reference to the construction of horse sheds on 6 March 1769 provides further evidence of a centralized house of worship:

Whereas our Brethern [sic] Thomas Cox son of Joseph, \& Jonathan Holmes, who were appointed to get ye Stable built, brought in their accounts \& ye subscription for building ye same, $\&$ there appeared a balance due to them of sixteen shillings, which was paid. ${ }^{8}$

This is a particularly early example of horse sheds being built by a rural church congregation for the accommodation of its attendees.

Two more minutes in the Church Book from the 1770s help to further establish a general construction date for the Upper Freehold Baptist meeting house. On 2 March 1772, it was recorded that:

At a quarterly church meeting, ye Church being convened, concluded to new Shingle ye meeting-house. That brother Tapscott procure the Shingles for ye purpose. ${ }^{9}$

Three years later, it was noted that:

At a meeting of Business, ye Church being meet whereas our Brother William Tapscot hath procured Shingles to new cover ye meeting-house - also boards to Seil [sic] ye inside and other materials and has got ye meeting house new Shingled; and has this day brought in his account \& the Subscription, \& there appeared to be money due to him - for which he consent to balance for 36 Shillings - which was paid or discounted by Thomas Farr. ${ }^{10}$

First and foremost, these minutes in the Church Book confirm that the building was old enough by the early 1770 s to require installation of a new wood shingle roof. The average life expectancy for such a roof in the eighteenth and nineteenth centuries was roughly 40 years, reduced to about

\footnotetext{
${ }^{7}$ Church Book Transcript, Introduction.

${ }^{8}$ Ibid, 6 March 1769.

${ }^{9}$ Ibid, 2 March 1772.

${ }^{10}$ Ibid, 19 June 1775.
} 
twenty years today without careful maintenance and periodic chemical treatment. ${ }^{11}$ If the average of forty years was indeed applied to the Upper Freehold meeting house, then the structure might well date from 1737 as the roof then needed replacement after about thirty-five years. This early date of construction is therefore vindicated, even though there are no other timber framed houses of worship in the area from that era to which it can be compared, and with no further documentary evidence available at this time. $^{12}$

The 1775 reference to "boards to Seil ye inside" provides important insight into what the interior of the meeting house might have looked like in its first four decades of use. It may have been nothing more than a framed and enclosed shell of a building with few if any interior appointments. The term "Seil" refers in the eighteenth century to a ceiling. So some thirty-eight years after presumed construction, the Upper Freehold meeting house was finally provided with a ceiling of wooden boards, thereby hiding the roof framing from view. Such ceiling treatments were also installed in nearby Old Tennent Presbyterian Church of 1751-52, and when St. Peter's Episcopal Church in Freehold, begun in 1771, was finished after the Revolution. ${ }^{13}$

Two citations in the Church Book from the 1780s give further information about finishing the interior of the meeting house. The first, dated 5 December 1785, reads as follows:

Quarterly meeting of business, Concluded to Seat the Meetinghouse below Stairs, and get a Stove in the same. ${ }^{14}$

Six months later, the second entry states:

\footnotetext{
${ }^{11}$ When the roof of the Holmes-Hendrickson House in Holmdel, NJ, built about 1754, was replaced in 1981, original nailing strips for the shingles were examined closely for rows of nail holes. It was determined at the time that five roofs had been installed previously, for an average life of 45.4 years each.

${ }^{12}$ Dendrochronology could in the future help to further refine when the framing timbers were originally cut.

13 The ceiling of wooden boards at Old Tennent Church in Manalapan remains in place to this day. That at St. Peter's Church was replaced with plaster in the nineteenth century.

${ }^{14}$ Church Book Transcript, 5 December 1785.
} 
Quarterly meeting of business. Proceeded to enquire into the temporal affairs of this Church, and find her indebted £16., 8., 7. This day paid to Tobias Hendrickson for Larth and Boards the sum of $£ 1$. 7. 6. Agreed also that the debts be paid as soon as may be. ${ }^{15}$

To summarize, between December of 1785 and June of 1786, work on the meeting house included the apparent provision of benches on the main floor of the building, installation of a cast iron stove for heat, and the application of lath and apparently plaster on the walls. After 49 years of use, the Baptists of Upper Freehold could take pride in worshipping in a completed meeting house up to the standards of the day. The Rev. Morgan Edwards described the building as "finished as usual" in his comments published six years later, and also confirmed the presence of a stove. It may have been similar to one purchased in 1773 for use in the Chesterfield Friends Meeting House in nearby Crosswicks. That wood stove, which survives in place today, was cast at the Atsion Iron Works in Burlington County. ${ }^{16}$

So by the end of the eighteenth century, what did the Old Yellow Meeting House look like? It measured 26 feet by 36 feet, was two stories in height, and featured a simple gable roof. The three bay south elevation contained two entrances on the first floor, and three windows above. The two bay east elevation contained windows at both levels, with a doorway into the graveyard now closed between those of the first floor that probably led to an interior cross aisle. ${ }^{17}$

\footnotetext{
15 Ibid, 19 June 1786.

${ }^{16}$ Charles S. Boyer, Early Forges \& Furnaces in New Jersey (Philadelphia: University of Pennsylvania Press, 1911), 172.

17 The framing of the door was discovered during extensive structural repairs and re-siding of the east elevation in 1977/78.
} 


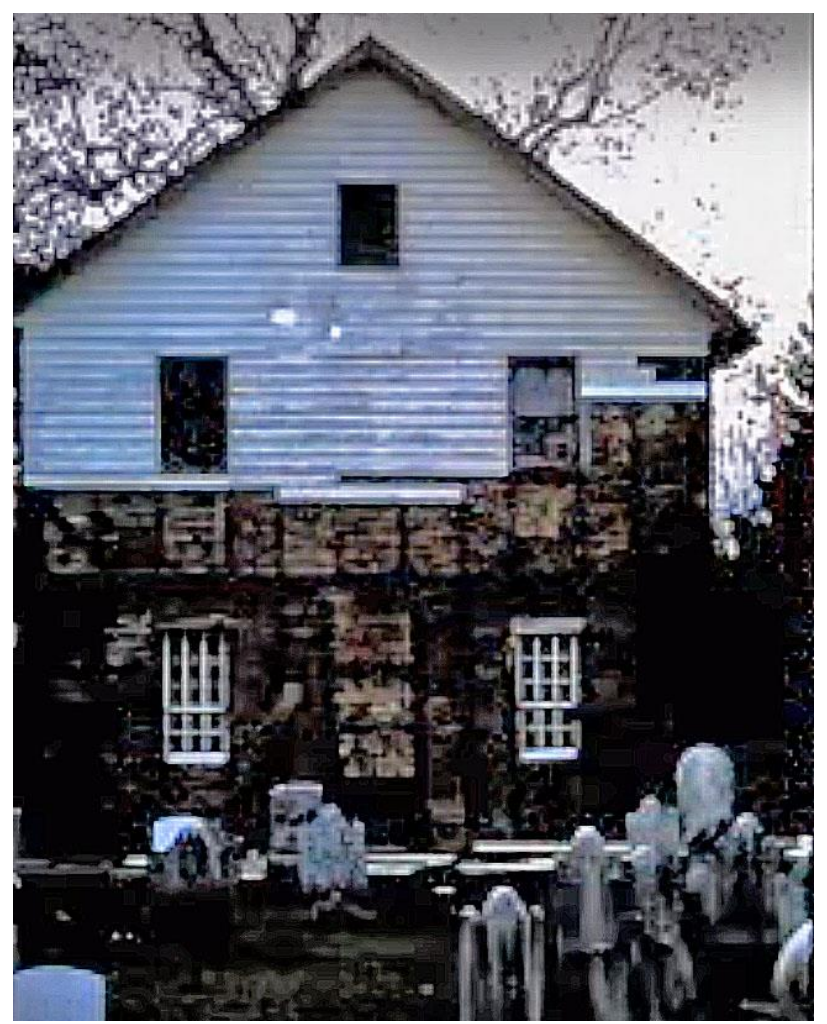

The east elevation being stripped of its siding in 1977/78. Framing for an early door closed up in 1836 is centered between the two first floor windows. Photo courtesy of a slide show created in 1980, available online at www.oymh.org. Hereafter credited as "OYMH Slide Show."

Siding consisted of beaded weather boards, with brick nogging in the walls. The doors, three of which survived into the $21^{\text {st }}$ century, had six raised and beveled panels on the exterior, with flush beaded vertical boards on the interior. ${ }^{18}$ They were secured in place by 24 inch wrought iron strap hinges. The building was placed on a fieldstone foundation laid up dry. On the interior, galleries were built on the east and west gable ends. Cut off remnants of the east gallery framing were discovered during structural work in the northeast corner of the meeting house carried out in $1977 / 78$.

\footnotetext{
${ }^{18}$ The only exterior door to remain intact today is the north door on the west elevation. The south door was badly damaged during a break-in in the 1970s, and was repaired. The east door on the south elevation was replaced in its entirety recently with a new paneled replication of the original, varying only with exposure of the panels on the interior rather than vertical boards with beads.
} 


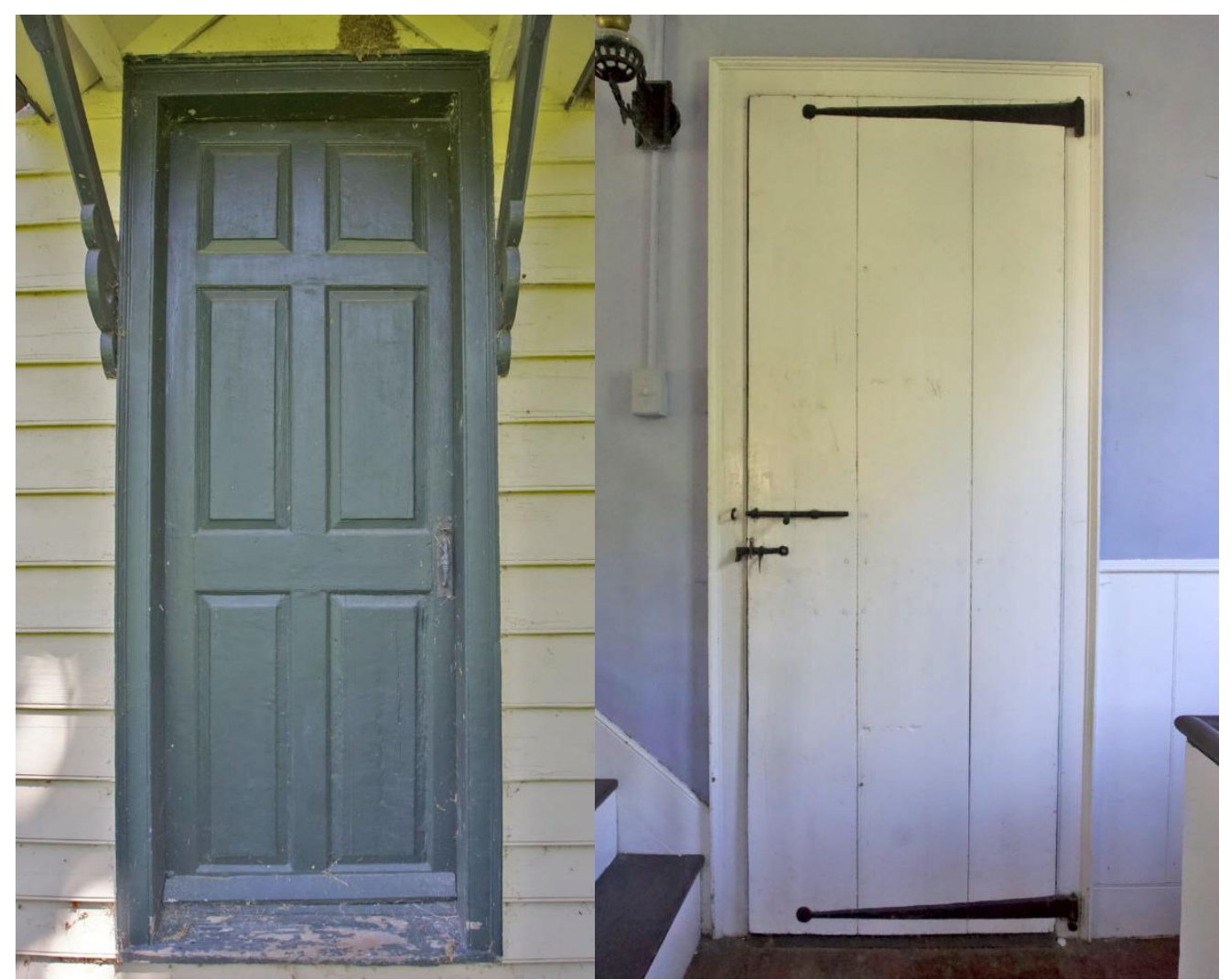

Exterior and interior views of the north door on the west elevation. Note the early wrought iron strap hinges, as well as the iron latch and lock. The exterior hood over the doorway was added in 1877. Courtesy Sheila Koehler.

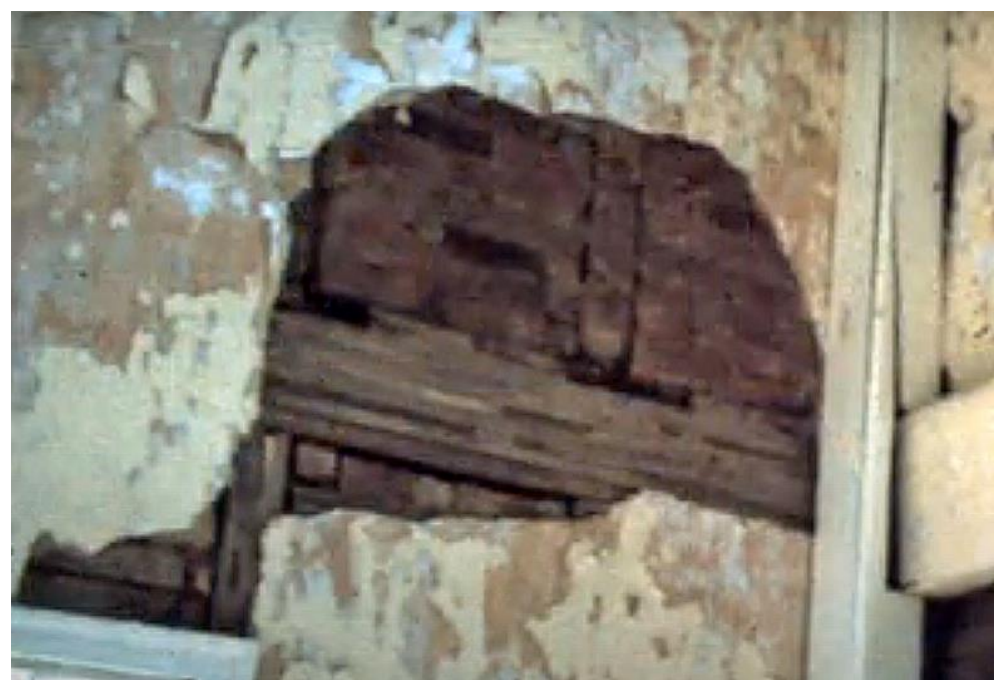

A cut off support timber for the east gallery was uncovered during restoration work in 1977/78. It can be seen sitting on the top surface of the exposed wall girt where plaster had been removed. Note also the pale yellow paint on the plaster, with light blue showing under it. Courtesy OYMH Slide Show. 
The height and depth of the east gallery remained obvious due to patches in the plastered walls until most early plaster was removed from the building in 1990. Evidence now lost also indicated that a modest pulpit or speaking platform once existed in the center of the south wall between the two entrances. The benches, with cut out ends and held together with hand-wrought nails, would have faced the platform and doorways in what is called a reverse meeting house plan oriented on the short or transverse axis of the building. They resemble closely seating arrangements found in eighteenth and early nineteenth century Friends meeting houses in the Delaware Valley and New Jersey area. Benches in the Chesterfield Friends Meeting House at nearby Crosswicks, Burlington County, are very similar in style although ten years earlier and slightly heavier in construction. Some of the Old Yellow Meeting House benches were reinstalled with modifications in the west gallery in 1836 . The board ceiling and cast iron stove complete what we know of the early interior appointments.

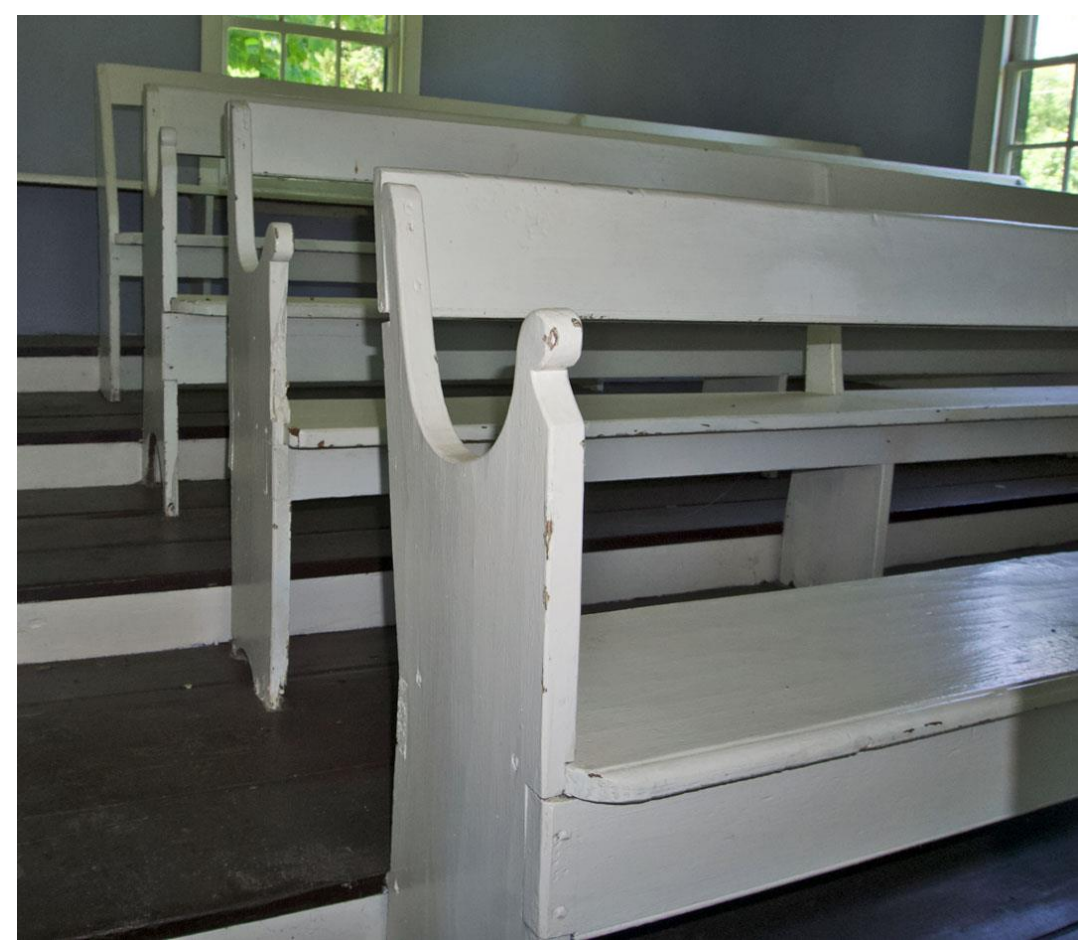

Benches on the north side of the west gallery, which appear to date from 1786 and were reused during the 1836 rebuild of the meeting house. Note the use of hand-wrought nails during assembly. Courtesy Sheila Koehler. 


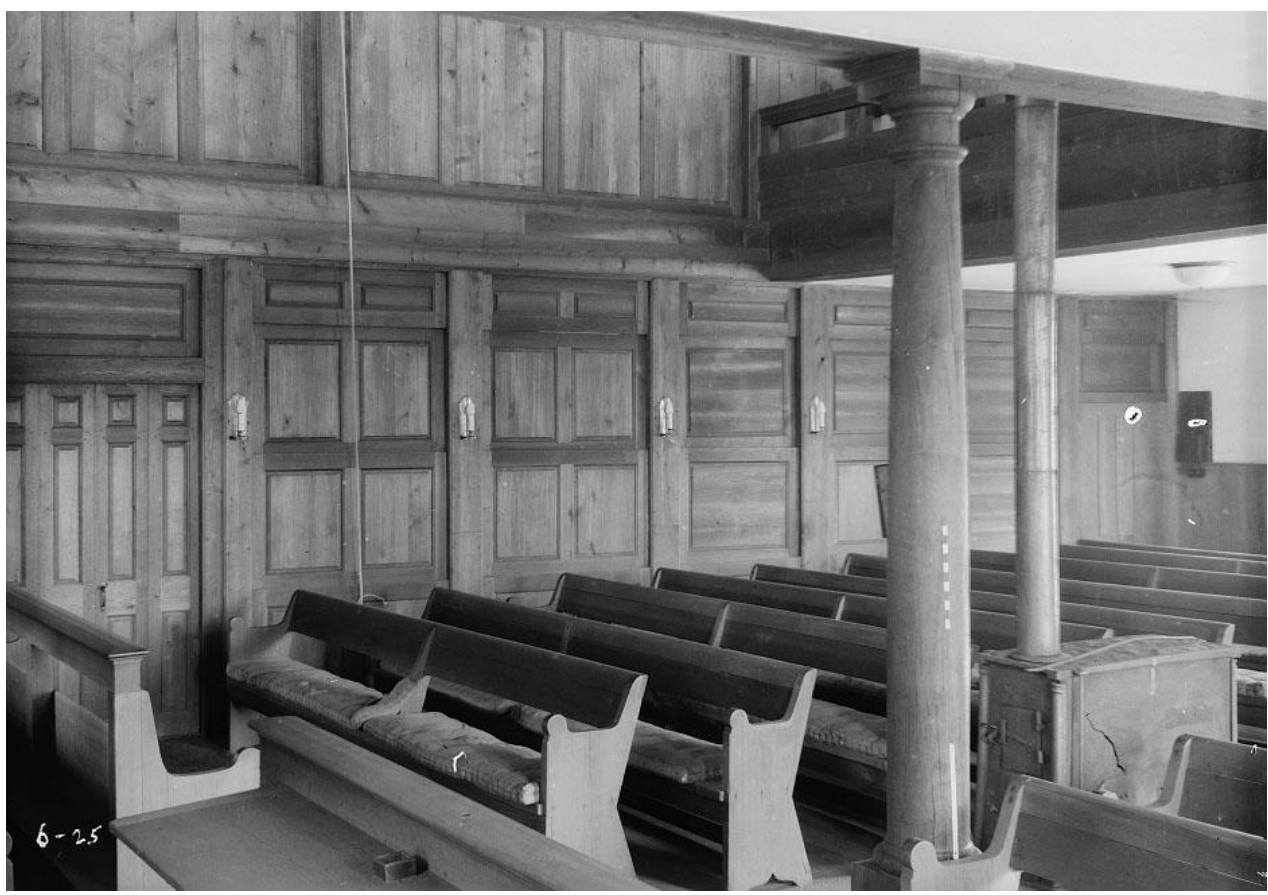

An interior view of the Chesterfield Friends Meeting House in Crosswicks, Burlington County, built in 1773 -

76. Located about ten miles from the Old Yellow Meeting House, the benches are similar in form and construction to those in the Baptist meeting house, although ten years earlier. Note also the iron wood stove cast at the Atsion Iron Works which was purchased by the Crosswicks Friends in 1773. Historic American Buildings Survey, courtesy of the Library of Congress, Washington, DC.

When finished in 1786, the Upper Freehold Baptist Meeting House closely resembled the contemporary Mount Bethel Baptist Meeting House in Somerset County mentioned above, built new in the same year. Both shared the reverse floor plan, two entrances on the south elevation flanking a pulpit, two internal galleries, and a third gable end door leading to their respective graveyards. Stairs to the galleries at Mount Bethel are located in the south corners of the interior adjacent to the two main entrances, suggesting where stairs might have been placed at the Old Yellow Meeting House. ${ }^{19}$

\footnotetext{
${ }^{19}$ Westfield Architects \& Preservation Consultants, op. cit., 2-9. The reverse meeting house plan was once commonly found in New Jersey, but nearly all examples have been changed to place a pulpit or platform on the wall opposite the entrances, and with the pews turned 180 degrees. Old Brick Reformed Church in Marlboro, Monmouth County, built in 1826 , retains its reverse plan to this day, a very rare survival.
} 


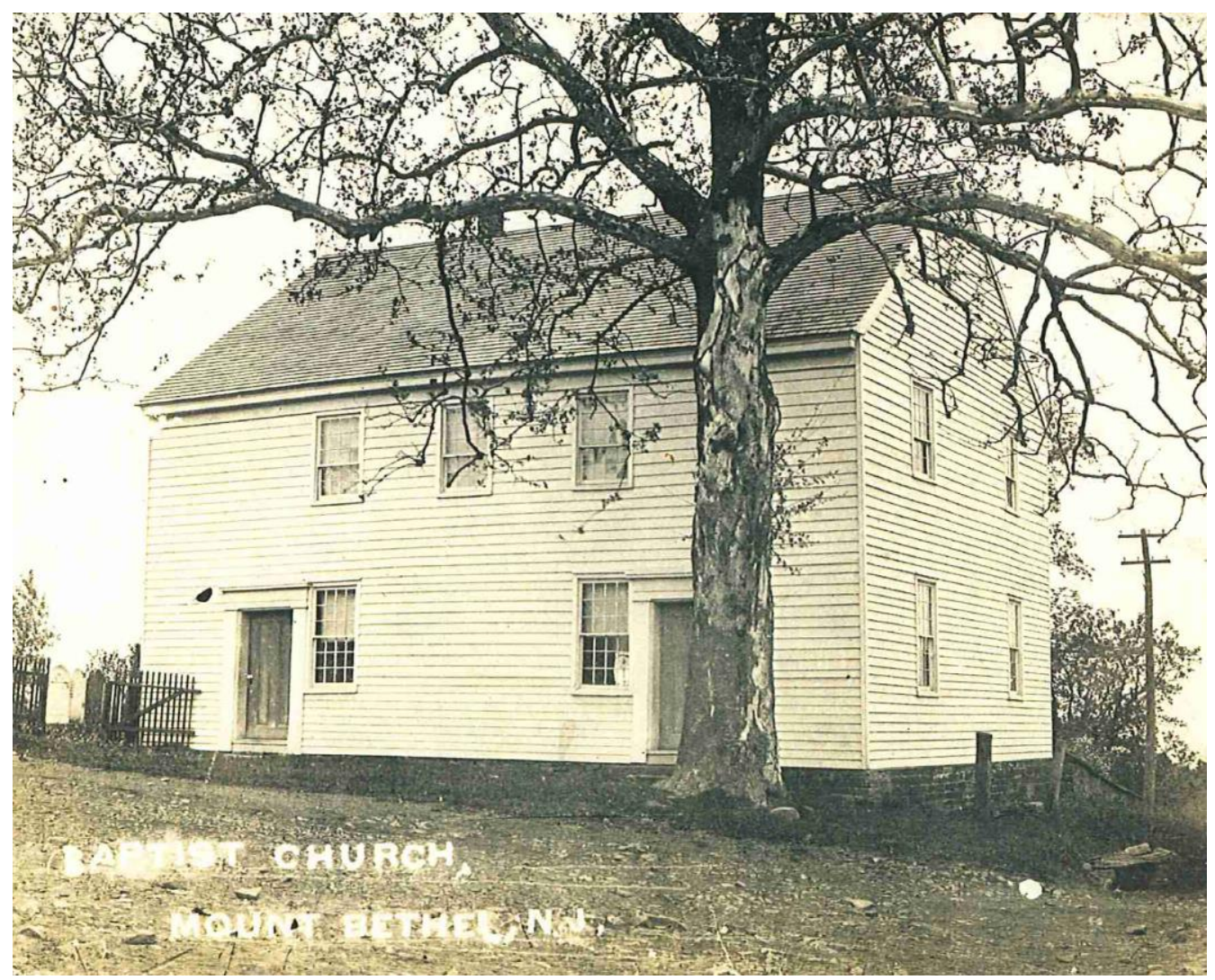

A historic image of the Mount Bethel Baptist Meeting House, built in 1786, taken from an early $2^{\text {th }}$ century photo post card. The blank space between the two first floor windows reflects the former presence of a high pulpit on the interior side of that wall in what is known as a reverse meeting house plan. The pews faced the pulpit and two entrances. The interior was changed to a more conventional arrangement in 1887 , with the pews turned 180 degrees to face a new platform located on the north wall opposite the entrances. Courtesy Westfield Architects \& Preservation Consultants, Haddon Heights, NJ.

For much of the late eighteenth and early nineteenth centuries, the Upper Freehold Baptist congregation experienced a frequent turnover of their ministry, a situation common among small rural churches with limited financial resources. That changed in 1822 when the young Rev. James M. Challis (1799 - 1868) settled among them at the age of twenty-three. His pastorate was later described as follows:

His settlement was an era in the history of the church. A new epoch began. His piety was diffusive and he had a receptive welcome among his people. He was ordained in December 1822 and during sixteen years of happy and appreciated labors, harvested continuously for the Kingdom of God, averaging annually the baptism of fifteen converts. Considering the low estate to which the church had fallen in the long time that preceded the coming of Mr. 
Challis..., the labors of Mr. Challis must be esteemed as an especial endowment of the Holy Spirit. ${ }^{20}$

During his sixteen years of service, the Rev. Challis received into the church on profession of faith 238 converts, or more than half of all those who joined the congregation up to $1900 .^{21}$ His remarkable success among the Baptists in central New Jersey no doubt put a stress on the seating capacity of the ancient meeting house in Upper Freehold, at that point nearing 100 years in age. So in 1836, a major expansion and renovation of the building took place.

Three entries in the Church Book again provide a framework for when the changes occurred. The first, dated 2 April 1836, resolved where the congregation would meet while their meeting house was under construction.

A kind invitation having been received to occupy the Methodist Meeting House of Wrights Mill while we are Repairing ours, therefore it was unanimously

Resolved to thankfully accept of it, with the understanding that we present them a Publick Collection when we are done using their House. ${ }^{22}$

The second entry of 1 October 1836 indicated that work still continued.

As the time of our Communion has been deferred until the Meeting House is Finished: it was resolved to hold a Saterday [sic] Meeting before the Sabbath, and so afford an opportunity for Candidates to apply for Membership.$-^{23}$

And the third dated 19 November 1836 documents when the newly renovated meeting house reopened.

A special Meeting, at the opening of our New House of Worship: after Sermon by Bro Challiss from the Text in Haggai 2. 7., the Church proceeded to Business - . ${ }^{24}$

\footnotetext{
20 Thomas S. Griffiths, A History of Baptists in New Jersey (Hightstown: Barr Press Publishing Company, 1904$), 212$.

${ }^{21}$ Franklin Ellis, History of Monmouth County, New Jersey (Philadelphia: R. T. Peck \& Co., 1885), 636.

${ }^{22}$ Church Book Transcript, 2 April 1836.

${ }^{23}$ Ibid, 1 October 1836.

${ }^{24}$ Ibid, 19 November 1836.
} 
The biblical text from Haggai, chapter 2, verse 7, chosen by the Rev. Mr. Challis suited the occasion admirably. It read: “And I will shake all nations, and the desire of all nations shall come: and I will fill this house with glory, saith the LORD of hosts." And it was no exaggeration when the minutes referred to the building as a new house of worship given the magnitude of the transformation that took place.

After the meeting house had been stripped of all its interior fittings, including the board ceiling and east gallery, a ten foot extension was added to the west end. This allowed for a change in interior orientation from the short or transverse axis of the meeting house plan to a longitudinal one reflecting the transition to a church. Two entrances were provided in the new west gable, with the east entrance on the south elevation remaining in place.

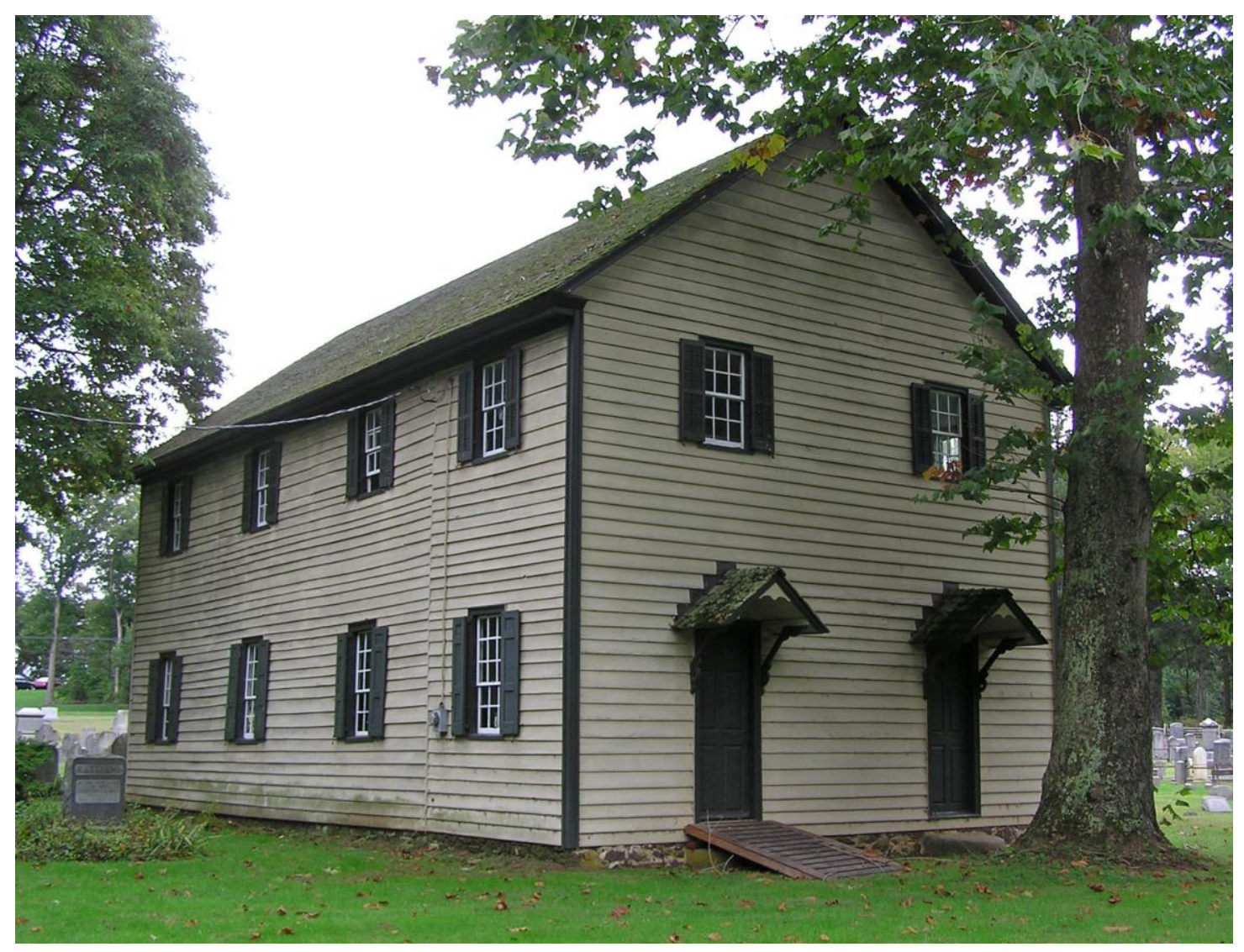

A view of the meeting house from the northwest, showing the 1836 extension and its two entrances. A vertical line in the siding to the left of the electrical service marks the joint with the earlier part of the structure. Courtesy commons.wikimedia.org. 
As mentioned before, the three eighteenth-century paneled doors were reused, plus a small piece of raised paneling recycled as an access hatch under the gallery staircase, the only obvious decorative early elements to survive. New but simple board bench pews in three banks separated by two aisles faced east toward a modest and restrained Greek Revival pulpit. Frontals for the pews featured raised paneling which matches the panels on the sides of the pulpit platform. ${ }^{25}$ A 21 foot deep gallery in the west extension was supported under its simple front rail by two attenuated turned columns. It incorporated the eighteenth-century gallery framing, and was accessed by an unusual T-shaped paneled staircase. The gallery benches were apparently reconfigured and reused from those installed on the main floor in 1786. A plastered ceiling over the sanctuary replaced the wooden boards. Appropriate fenestration changes reflected the building's new longitudinal axis, and new exterior clapboards were more or less matched on the south elevation to the originals. On the north elevation, the siding of the west extension merely butts against that on the existing meeting house, leaving a vertical joint in the siding. Some of the weather boards today have beaded edges, others are plain. It should be noted that all window sashes were also replaced at this time. After seven months of effort, the Upper Freehold Baptists completely transformed their aged meeting house into a neat and modern if plain house of worship.

${ }^{25}$ A careful examination of the pew ends on 3 August 2020 confirmed that the pews were never furnished with doors. 


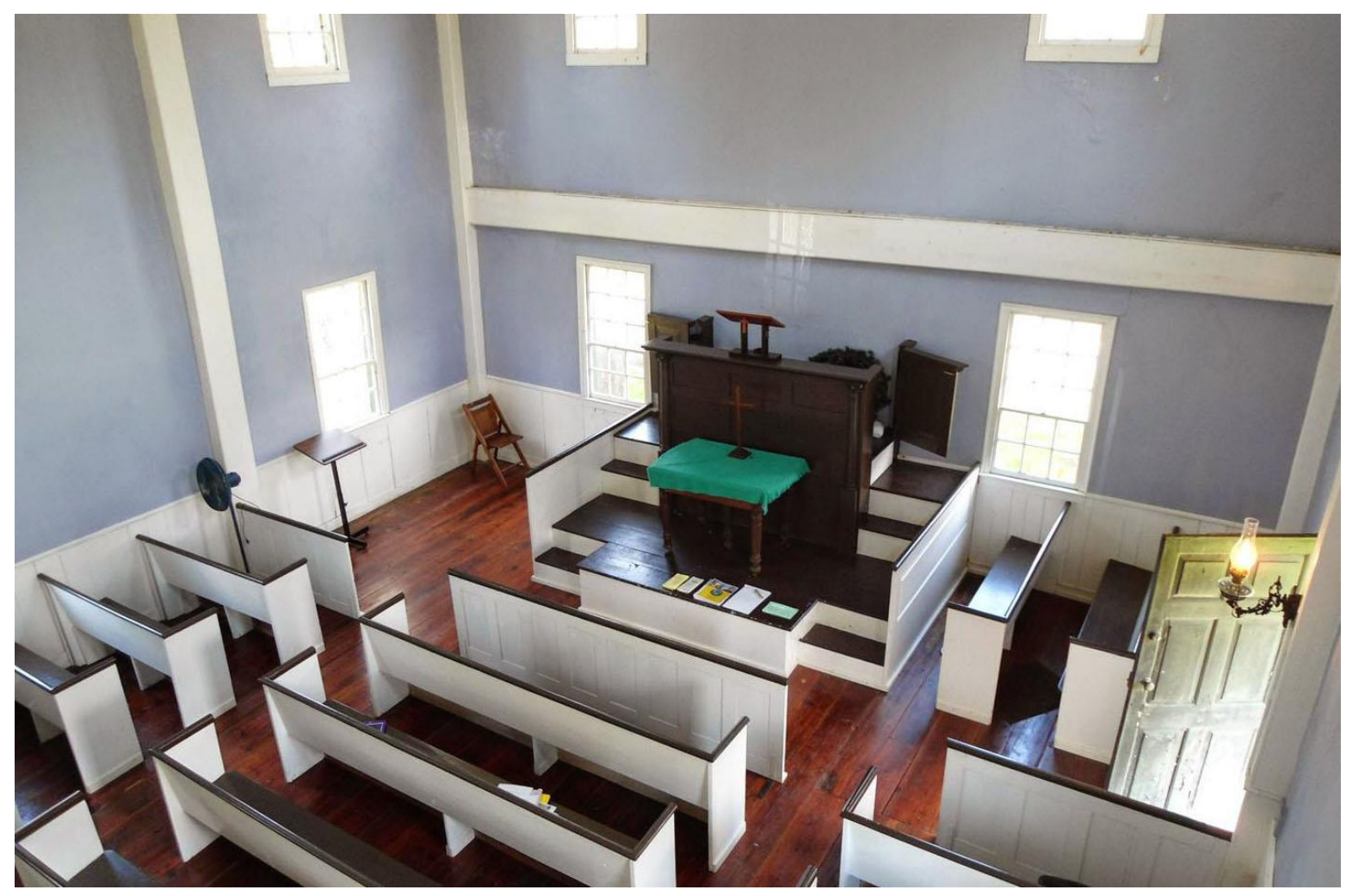

The east end of the meeting house interior as it has appeared since the 1836 rebuild. It featured simple board pews and a Greek Revival pulpit. Three pews to the left of the pulpit platform had been removed. Note one of the surviving eighteenth-century paneled doors on the right. Courtesy The History Girl as posted on Pinterest.

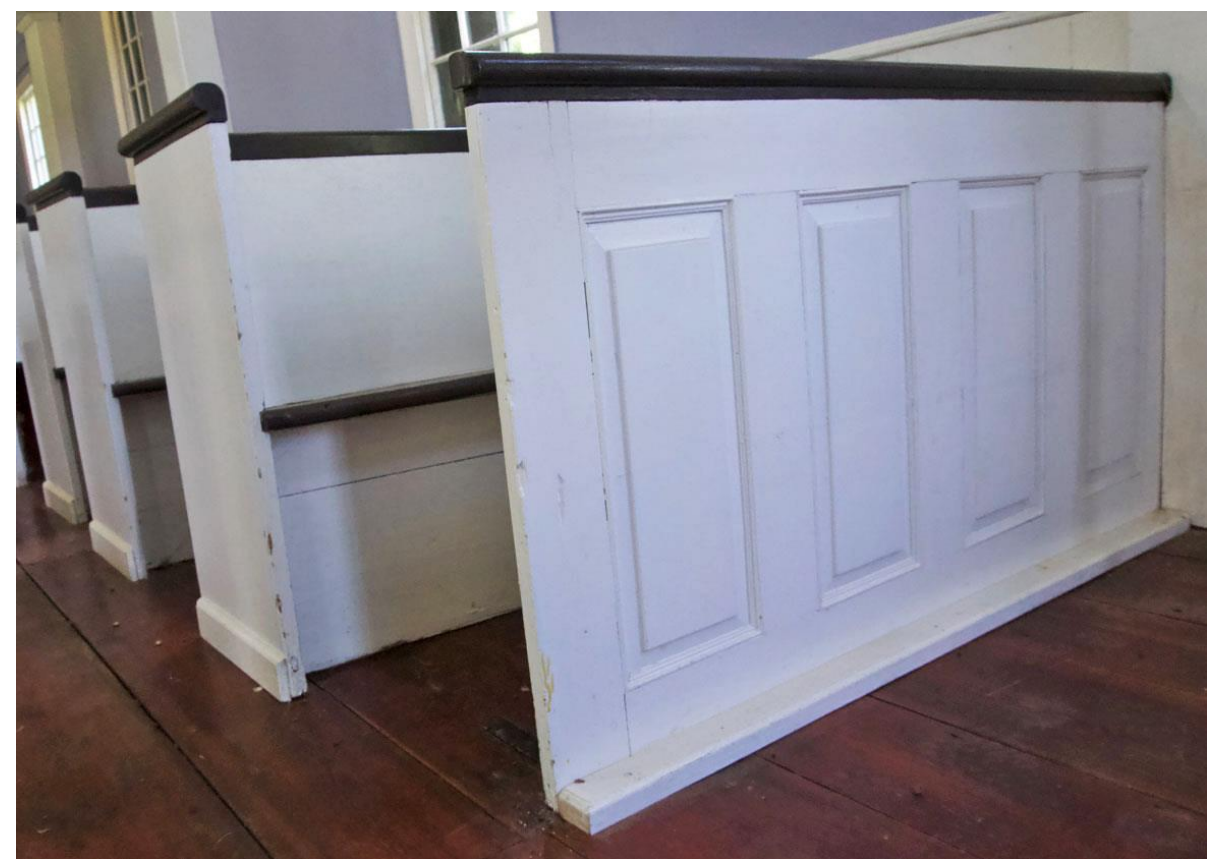

Detail of a paneled pew frontal and simple board pews on the first floor of the meeting house. The paneling matches similar woodwork on the sides of the pulpit platform and west gallery stairs. Courtesy Sheila Koehler. 


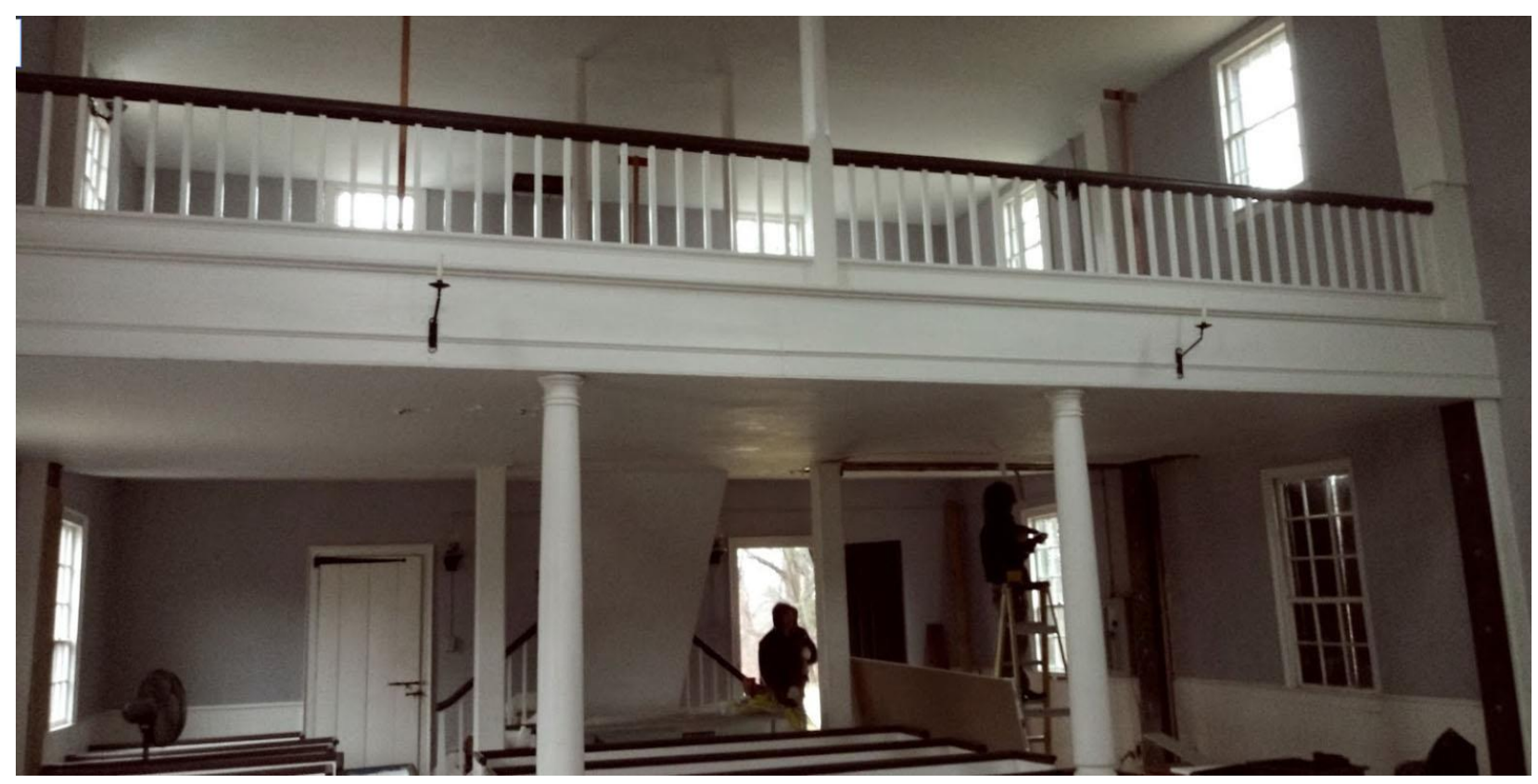

A view of the meeting house interior looking west, taken in December 2019. The 1836 gallery rail and turned columns that support it can be seen. Courtesy Richard Lore.

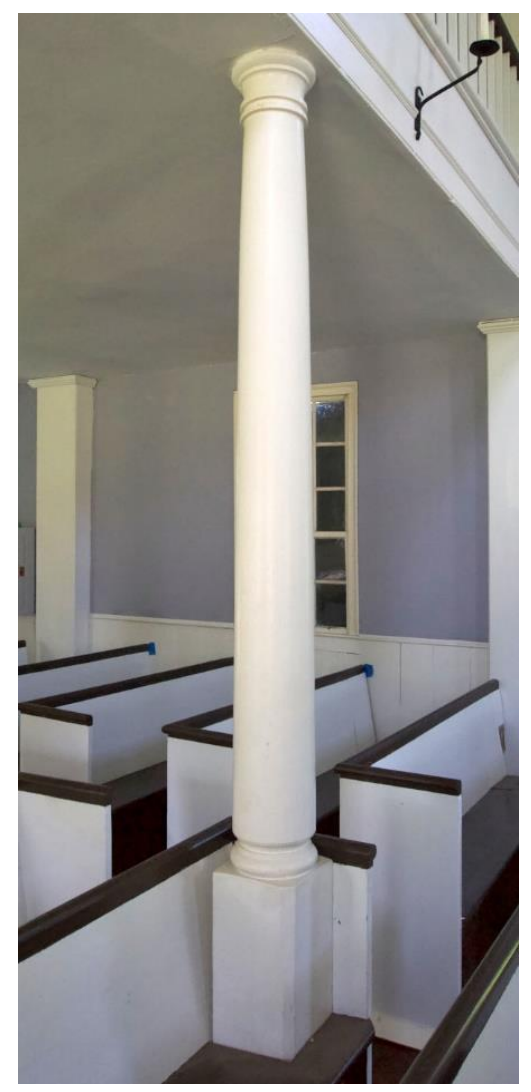

Detail of an attenuated turned column that supports the west gallery. Courtesy Sheila Koehler. 


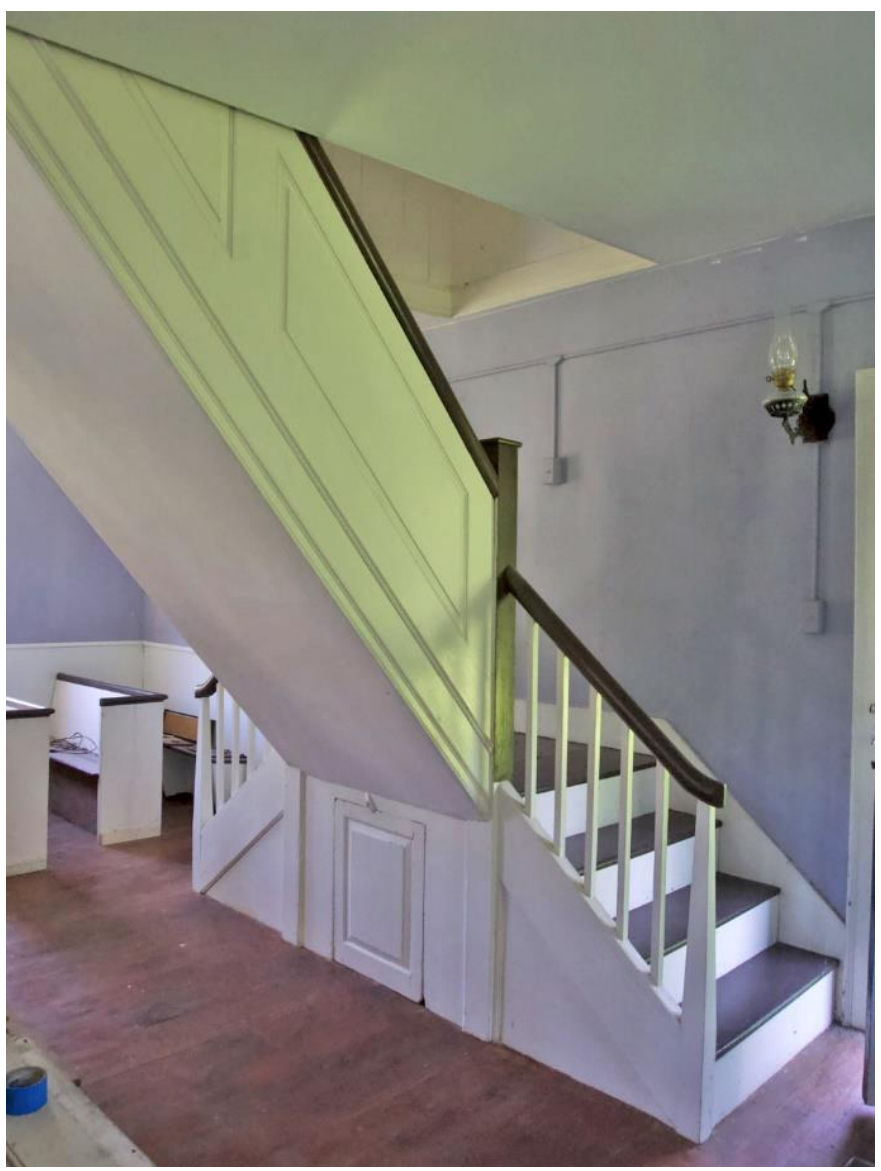

The unusual T-shaped stairway to the west gallery featured raised paneling. Courtesy Sheila Koehler.

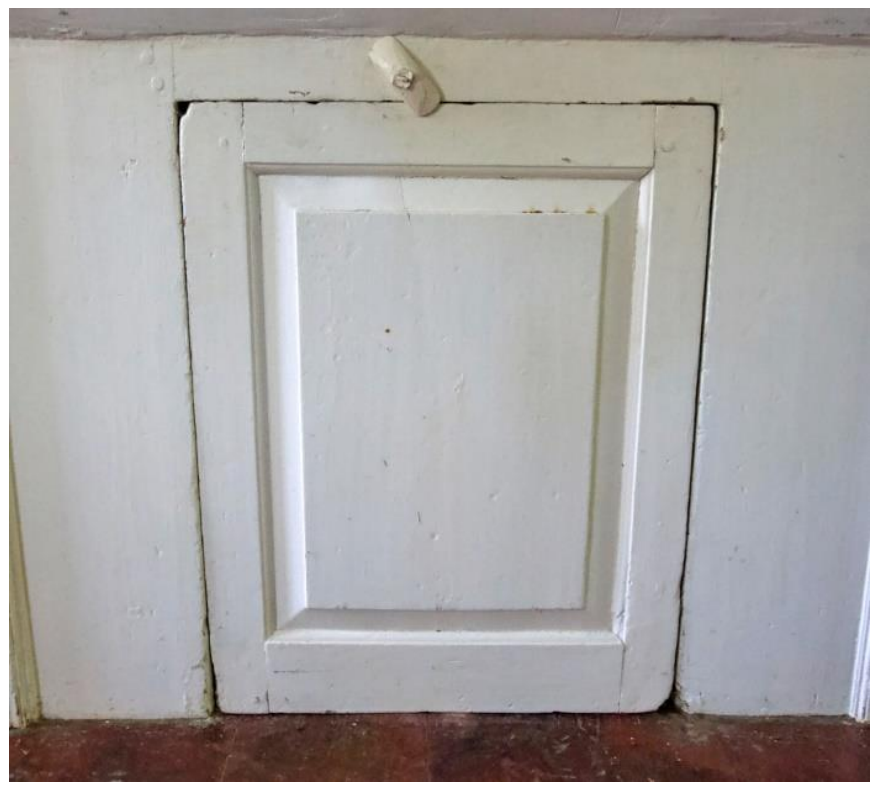

Detail of the small piece of eighteenth-century paneling reused as an access panel under the gallery stairs. Courtesy Sheila Koehler. 
In spite of its very rural location surrounded by farmland, those individuals who planned the meeting house renovations were in touch with the latest trends in church architecture. By the mid-1830s, many ministers were advocating the removal of high pulpits. One article that appeared in the Religious Magazine issue of February 1835 commented that:

It would be about as well to preach from the steeples of some of our churches, as from the pulpits. But time and the march of modern improvement are fast tearing down these huge edifices, from whose giddy height our unfortunate predecessors were compelled to shout down, upon the upturned heads of the congregation below.

The article then continued:

We are led to these remarks by having recently seen a pulpit in the congregational church in Shrewsbury, Mass. It is a beautiful pier table, placed upon a platform a little elevated above the congregation. It more perfectly corresponds with our idea of what a pulpit should be, than anything else we ever have seen. There is an air of ease and elegant freedom about it, which we never before have seen attained, in the most costly specimens of pulpit architecture. $^{26}$

An engraved plate of the Shrewsbury pulpit accompanied the article. It depicted a low table or reading desk placed on a raised platform accessed by stairs on both sides. The pulpit itself featured columns with carved capitals flanking semicircular paneling ornamented with carved swags. A sofa behind the pulpit provided seating for the minister. Above that, draperies were hung in a tall arch, thereby creating an imposing architectural composition. The article concluded by stating that:

The cost of this beautiful pulpit was but sixty dollars, exclusive of the sofa. The society in Shrewsbury must be one of more than ordinary intelligence, thus to break away from long established custom, and to adopt a plan so peculiarly marked with utility and taste. We are persuaded that few building committees, after seeing this pulpit, would persist in the prevailing practice of boxing up the minister. ${ }^{27}$

\footnotetext{
${ }^{26}$ The Religious Magazine, by the Messrs. Abbott (Vol. II, No. 5, February 15,1835), 202 - 204. The writer is indebted to Philip D. Zimmerman of Lancaster, PA, for bringing this article and its accompanying plate to his attention.

27 Ibid.
} 


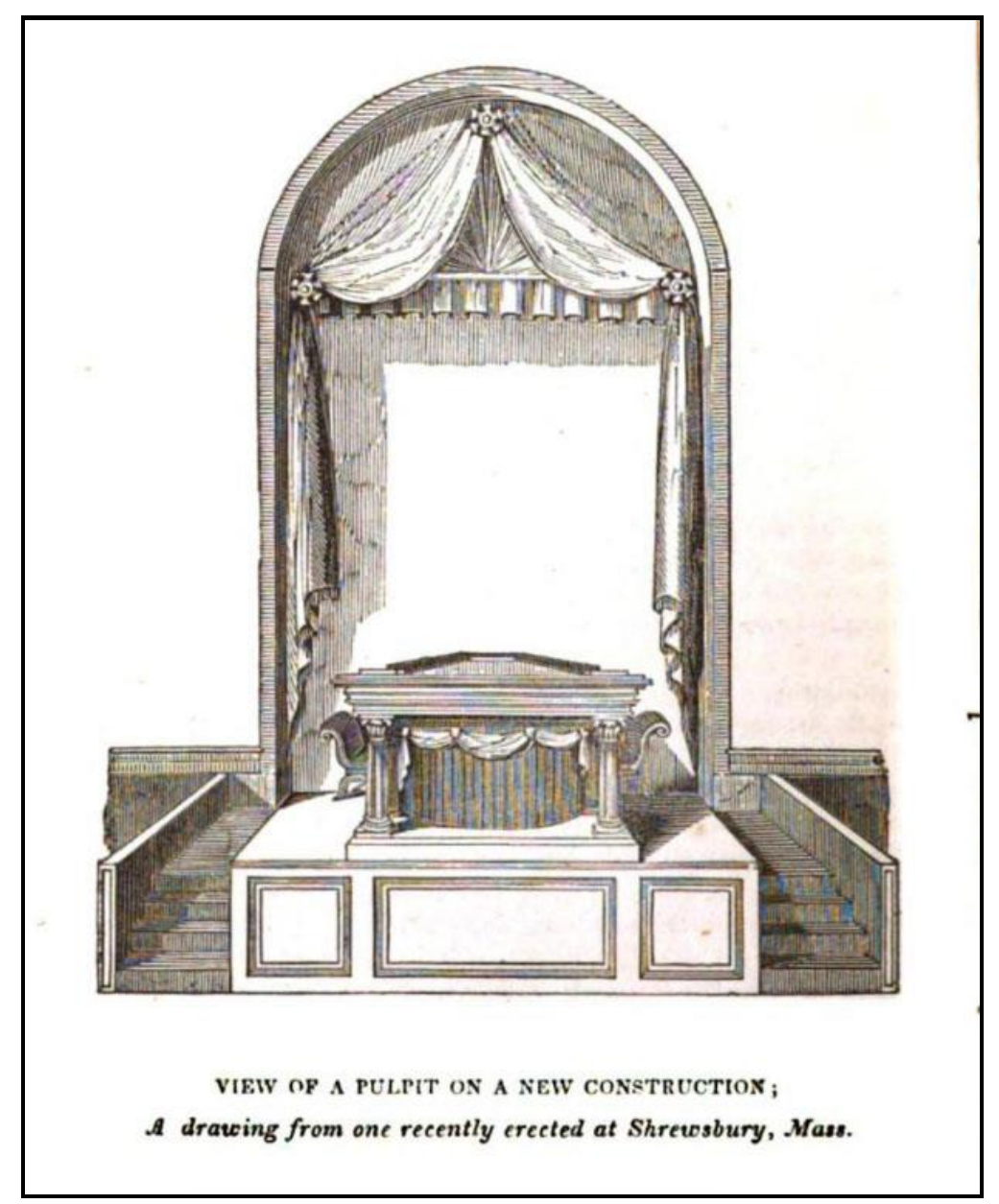

A plate from the Religious Magazine, by the Messrs. Abbott (Vol. II, No. 5, February 15, 1835), 202. The type of pulpit shown in this illustration served as a model for that installed at Old Yellow Meeting House the following year. Courtesy Harvard University, Cambridge, MA, as digitized by Google Books.

The restrained Greek Revival pulpit installed in 1836 at the Old Yellow Meeting House follows this latest model very closely. Made of cherry wood and with steps on both sides, it is raised up on a platform, in this instance to a second level so that people seated in the west gallery could be seen by the minister. The front of the pulpit consists of four rows of three horizontal flat panels each, which is then flanked by half-round columns surmounted by carved Ionic capitals. A chair instead of a sofa was provided for the accommodation of the minster, and the pulpit area was protected with two paneled gates, one on each side. A table was placed on the platform at the first level, in front of the pulpit. The quality and details of workmanship in the cherry wood parts of the 
pulpit suggest that a cabinetmaker produced it, rather than the finish carpenters responsible for the rest of the joinery such as the pulpit platform and pews. This unknown craftsman used different molding profiles more in keeping with the Greek Revival period, and flat fielded panels rather than raised. He also demonstrated competent skill in being able to carve Ionic capitals. Although simplified and modified to suit local conditions, the Old Yellow Meeting House pulpit clearly reflected a type only then coming into popularity, and as illustrated in the Religious Magazine in 1835.

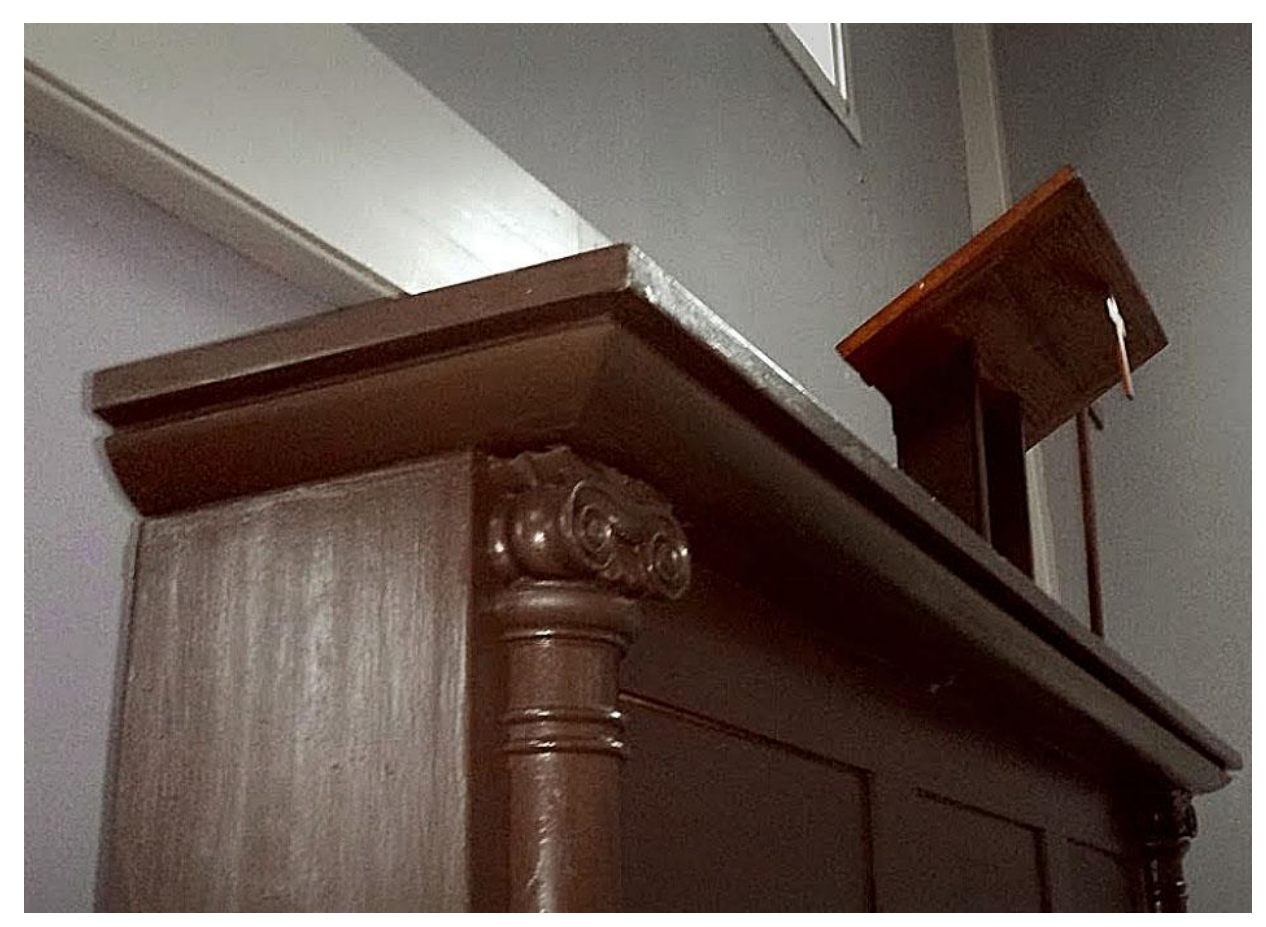

Detail of a carved Ionic capital, column, bold moldings, and flat panels that ornament the 1836 restrained Greek Revival pulpit, which is made of cherry wood. The reading stand is a recent addition. Courtesy Richard Lore. 


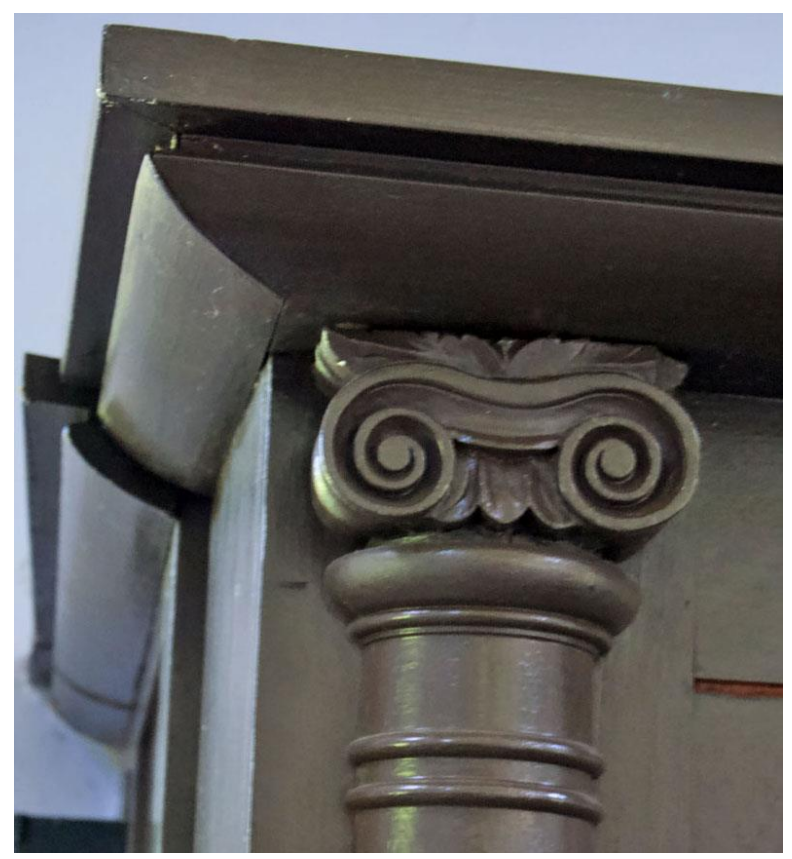

Closeup detail of an Ionic capital that ornaments one of the two half columns on the front of the pulpit. Courtesy Sheila Koehler.

Once the rebuilding of the meeting house was finished, the question arose about ownership of the pews, the sale or rent of which represented a longstanding traditional means of helping to finance the cost of church construction and renovations. On 23 February 1838, the issue came to a head.

The question having been agitated for some time past about the propriety of Renting the Pews; it was resolved at this Meeting that the Pews shall be free.$-{ }^{28}$

Paying for the project, however, was still a major issue into 1839. On 5 January,

There was also a committee appointed consisting of Bro Combs, Fenton \& Tunis to raise money by subscription to liquidate the debt occured [sic] by repairing the Meeting House. ${ }^{29}$

Three months later, "The committee to raise money to defray Church debt Reported - Progress." 30 The Rev. Mr. Challis did not long enjoy the fruits of his labors. He accepted in 1838 a call to

${ }^{28}$ Church Book Transcript, 23 February 1838.

${ }^{29}$ Ibid, 5 January 1839.

${ }^{30}$ Ibid, 6 April 1839. 
Lower Dublin, Pennsylvania, leaving behind an enduring monument to his pastoral successes in central New Jersey.

As the nineteenth century progressed, the extremely isolated rural location of the Old Yellow Meeting House became a handicap, especially to those increasingly prosperous farm families who lived miles to the west. A 1907 history of the congregation tells the story.

In the stirring spiritual seasons of the Old Yellow Church, the people for many miles around found that a most attractive center, and for many years worshipped there regularly until the Cream Ridge part of the Crosswicks community wished for a place of worship nearer their fine farms. So, in 1846, a building was erected on the site of the present Presbyterian Church at Cream Ridge, and for eight years the organization conducted services at the Old Yellow Church in the morning and at the Cream Ridge Church in the afternoon, and a mission for evening service and prayer meetings was established in the village of Imlaystown.

In 1854, feeling that in unity there is strength, the two charges effected a compromise and resolved to have a central place of worship, when it was agreed to locate at Imlaystown. The building from Cream Ridge was removed and placed on a lot donated by Ann Ivins, a staunch Christian and a faithful worker in the denomination. This is the structure, after being enlarged [in 1864] and having annexed a beautiful chapel, the gift of Mrs. Martha Ann Holmes, that was burned about 4 o'clock on Sunday afternoon, July 5, 1903.

The main building at Imlaystown was $40 \times 70$ feet, and the adjoining chapel $18 \times 24$ feet, having ample space for hallways, robing rooms and entrances. Its high ceilings and good ventilation always proved an invigorating boon even during the crowded times and hottest seasons. The church had a high steeple and could be seen for miles around. After nearly a year's interval the new church was dedicated on Wednesday, May 25, 1904. It is a gothic structure valued at $\$ 10,000$, and contains all the equipment of any modern city church. ${ }^{31}$

Testimony in an 1858 Monmouth County court case involving the Rev. Samuel Sproul

(1812 - 1880, also frequently spelled Sprowl), pastor of the Upper Freehold Baptist Church from

1855 to 1857 , revealed that the politics and emotions of the move to Imlaystown were far more complicated than as described in the 1907 history.

Some two or three years since, Rev. Samuel Sprowl was installed as pastor of the Upper Freehold Baptist Church; the congregation at that time embracing three neighborhoods, each with its house of worship, but all belonging to one church and all composing a single

\footnotetext{
31 Allentown Messenger, 21 March 1907. The Cream Ridge Presbyterian Church building still stands, although long since converted into a private residence.
} 
congregation. The established place of the regular morning worship, for about a century past had, been at what has been long known as the "Yellow Meeting House," situated in a grove on the road leading from the "Stone Tavern" to the "Old Mill," or Clayton's mill, as it is sometimes called, about one mile from the latter place. A few years since another meeting house was erected at Cream Ridge, on the site now occupied by the new Presbyterian church edifice, in the South western part of the congregation limits. Still subsequently another meeting house of very modest pretensions, was built in the village of Imlaystown, where meetings were held on Sabbath evening, Sabbath afternoon service being held in the building at Cream Ridge. After the advent of Mr. Sprowl he took an active part in attending to the temporal concerns of the church, and mainly through his active and persevering efforts, against the will of a portion, quite a large and respectable portion of the congregation, the meeting house at Cream Ridge was taken down, removed and rebuilt at Imlaystown, and the morning services transferred, from the old Yellow Meeting House to the new building, and occasional afternoon services substituted in its place. To such an extent was the feeling agitated on this subject, that at length several of the "Old Church party" were excluded. Mr. Sprowl, with those who remained faithful to him, succeeded in establishing Imlaystown as head quarters [sic] of the church, while a large portion of the eastern part of the congregation refrained from attendance under the new order of things. ${ }^{32}$

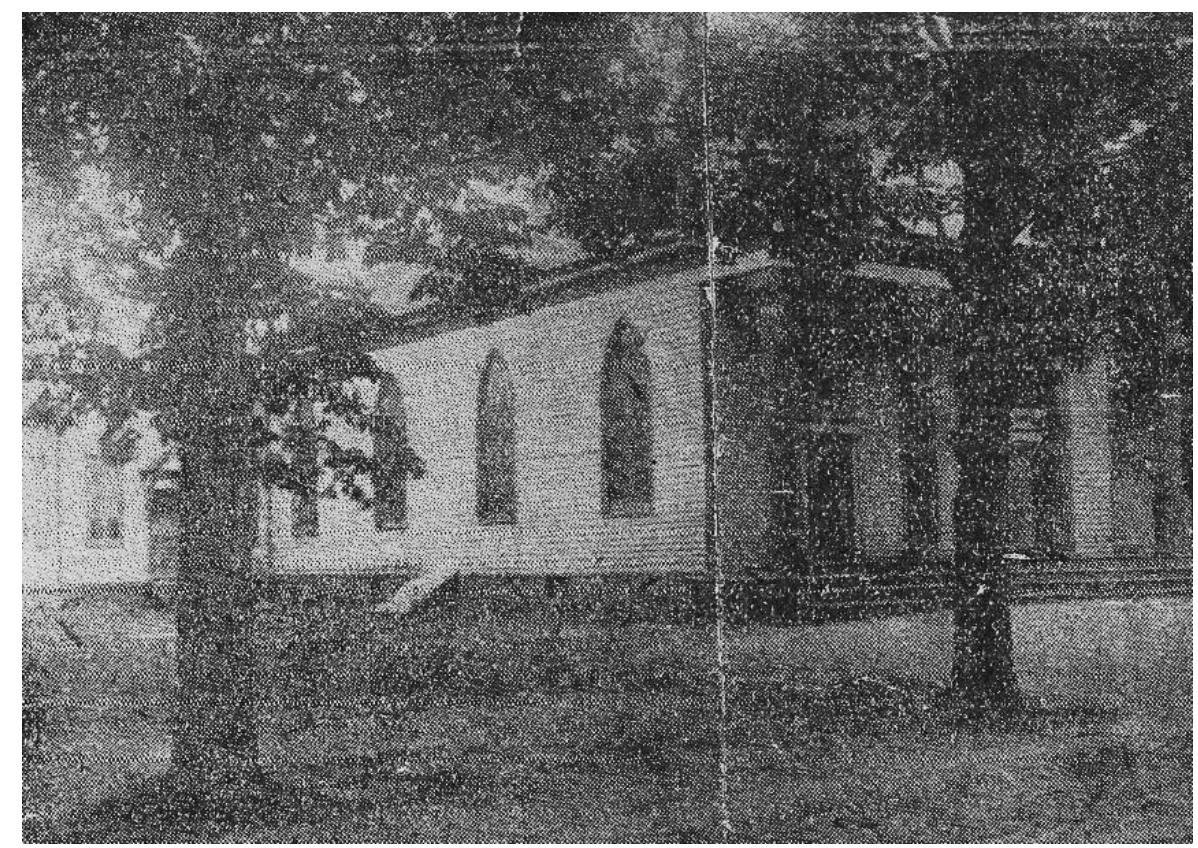

This grainy view of the Baptist church in Imlaystown appeared in the Freehold Transcript on 17 July 1903, twelve days after the building was destroyed by fire. The columned portico and a tall spire above it, which is hidden by foliage in this image, were added to the structure in 1864. Entrance to the $1890 \mathrm{Holmes}$ chapel can be seen to the left rear of the main church. No original print of this important photograph has so far been located. Courtesy Friends of the Old Yellow Meeting House Archive [hereafter cited as Friends Archive].

\footnotetext{
${ }^{32}$ Monmouth Democrat, 16 December 1858.
} 


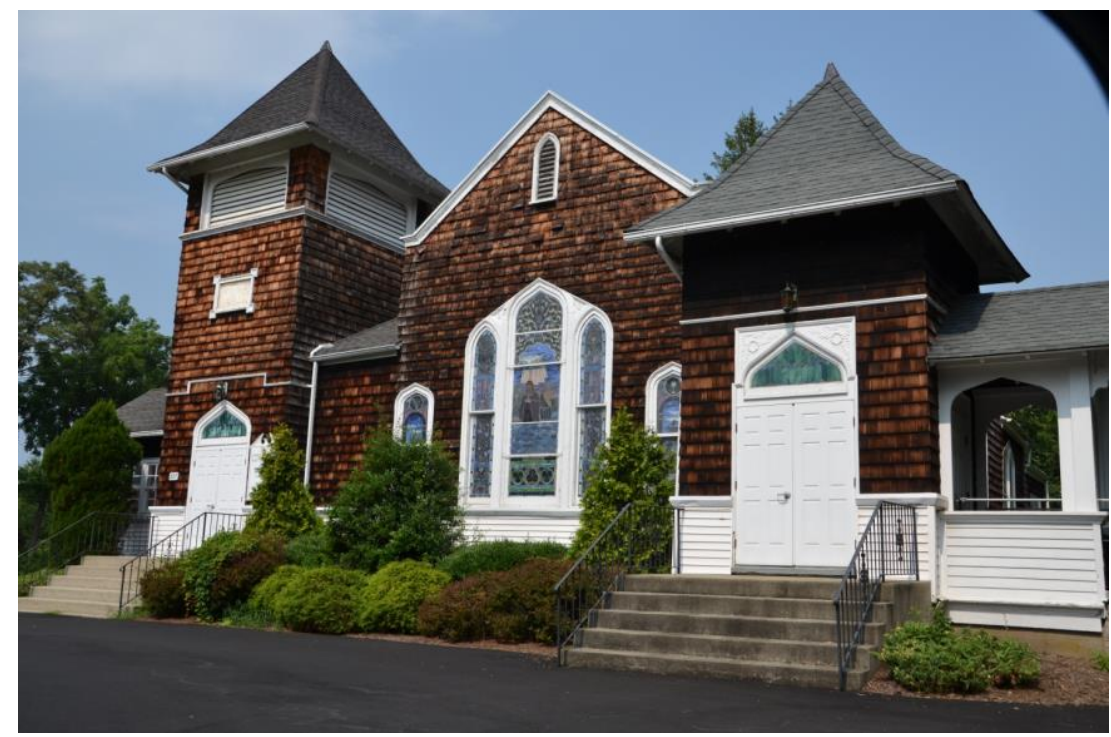

The Upper Freehold Baptist Church in Imlaystown, built in 1904 following destruction by fire in the previous year of their earlier church at this location. Although described as Gothic Revival at the time of its dedication, a stronger influence of the Shingle Style is apparent. Harry A. Hill of Trenton served as architect, and S. Leonard Sherman of Lakewood as contractor. The cost of the building and its furnishings came to $\$ 10,000$. Courtesy Flickr.

By 1855, the Old Yellow Meeting House had been relegated to occasional use for services and funerals, as a standby house of worship when the Imlaystown church was either being renovated or replaced after the fire, and as a popular place for social events, reunions, weddings, and historical pilgrimages. As early as 1877 ,

The Upper Freehold Baptists and their friends will unite in giving a Harvest Home in the Havens Grove, near Imlaystown, on Thursday, the $16^{\text {th }}$ of August. Object, repairs and renovation of the venerable "Old Yellow Meeting House." Where the Society formerly worshipped. $^{33}$

Collin B. Meirs had been appointed chair of a special committee on the day of the Harvest Home. Its purpose was "raising money wherewith to repair the Old Church building where the Society formerly worshipped and known as the 'Yellow Meeting House' ... [and] to carry out the object of the resolution - the committee thus appointed to have supervision of the contemplated repairs." 34 The scope of the work was unfortunately not described in the minutes. However, they

\footnotetext{
${ }^{33}$ Monmouth Inquirer, 19 July 1877.

${ }^{34}$ Upper Freehold Baptist Church, Minutes, 16 August 1877.
} 
appeared to be quite substantial. On 29 September, the committee reported that the Harvest Home had been held, and that:

a very considerable sum had been realized as would suffice in reference to the accompanying ac [sic] book of the Treasurer of the Committee. Also, that the Committee have proceeded at once to effect the repairs upon the Old Church building contemplated by the resolution under which they had been appointed, the work being now underway.

The Treasurer of the Committee, Bro. Joseph Holmes Jr., submitted the report above referred to, exhibiting the Committee's receipts and disbursements in detail, and showing a balance sheet of $\$ 425.75$ in favor of the entertainment. Both reports were accepted and the Committee as organized continued for the completion of the work at hand. ${ }^{35}$

The special committee submitted its final report on 23 March 1878.

The Committee of Harvest Home and repairs at Yellow Meeting House submitted through the Treasurer Bro. Joseph Holmes Jr. their final report showing net proceeds of Harvest Home \$426.75 and cash received from grave yard Com[mittee] \$37.41 making a total of 464.16. being the sum total of expenses incurred in alterations and repairs. Report accepted and Committee discharged with thanks. ${ }^{36}$

In all likelihood, extensive repairs undertaken at this time included the slate roof installed on the meeting house at some point in the late nineteenth century, along with a molded pottery chimney pot and slate covered hoods over the entrances. It had been forty-one years since the rebuild of the meeting house in 1836, thereby reaching the end of the average forty year life expectancy for a wood shingle roof.

An 1882 visitor commented that,

A visit to the old Yellow Meeting House shows that this ancient landmark is still in a good state of preservation, those dwelling in the neighborhood taking great pride in keeping the premises in good order. Its interior is even stranger than that of the Tennent Church; its pulpit is so small as to preclude the possibility of anybody's ranting even metaphorically in it; while the back seat in the gallery is so far away from the pastor as to afford a splendid lodging place should any one choose to use it as such. The new coat of paint is not so yellow as it might be but this only indicates the fact that a name, like a barnacle, will stick when most else is gone. The Rev. David Silver, pastor of the Baptist church in Imlaystown, preaches at stated intervals. ${ }^{37}$

\footnotetext{
${ }^{35}$ Ibid, 29 September 1877.

${ }^{36}$ Ibid, 23 March 1878.

${ }^{37}$ Monmouth Democrat, 31 August 1882.
} 
The most detailed historical description of the Old Yellow Meeting House known as of this essay was written in 1896 by William V. Cox of Washington, DC. In September of that year he made a four-day trip to the Cream Ridge section of Upper Freehold in order to visit relatives, as well as cemeteries and historic sites of family interest, to collect genealogical information. Cox's diary is quoted here at length, in part to demonstrate how few changes have been made at the meeting house in the intervening 125 years. Accompanied on 6 September by his cousin William Emley Cox, he wrote:

The building is a frame weather boarded structure about 50 feet long and 27 feet wide, barn shape $\&$ painted yellow. It has 2 rows of windows on each side, 4 below and 4 above. The former contain 15 panes of glass about $6 \times 8$ in. Those above 12 . Five windows are on the west $\&$ east side. The entrances are on the west and south sides. Main entrance on west side, other leads to graveyard. Pulpit about 7 feet from floor level, closed in by gates, at the east end of bldg. Platform about 2 feet high surrounding the pulpit, the front of which is cherry paneled -12 panels 3 [text omitted] in width. There are two pillars on either side of pulpit, the capitals of which are in rams horn design. A reading desk with fringe and tassels on either corner surmount the pulpit. A table is [on the] floor in front of the pulpit.

On this table was a Bible given this old Baptist Church in 1845 by Apollo Meirs, great grandfather of Mrs. W. E. Cox. Two hymn books were on either side dated 1846. On the fly leaf of one I found a memorandum that Mary Cox had contributed 150.00 for church expenses. The pews face the pulpit -13 on the side, ten in the center, and three on either side of the pulpit. They are of pine and almost perpendicular, and about 3 feet high. A gallery is at the west end and extends over 8 pews. There are 6 seats on a side in the gallery, the stairs passing thro the middle. The doors at the main entrance contain 3 plain boards, and hinges nearly a yard long. Old fashioned latches fasten the doors. A panel door is on the south side near the pulpit. A large white oak beam shows in the wall above the pulpit14 or 16 in[ches] wide. Five posts in the wall sustain the framework of the roof. These have been cased in mill boards. The church was heated by a stove in the centre, the pipe of which went thro the roof. The shutters on the windows are painted green and fastened by fish plate fastenings. Solid blinds are on the windows below, but above they are latticed. Bats made their house behind the upper shutters and I counted nine in one window. A piece of plastering has fallen from the ceiling. A large pudding stone [text not legible] the entrance at south about $6 \mathrm{ft}$ long $1 / 2$ foot wide. The steps at the west doors are made from an old mill stone cut in pieces. Services have not been held in the church for several years, and no regular services have been held in the life of W. E. Cox. The walls above the wainscoting inside are of blue tint, wainscoting painted white and about $31 / 2$ feet high. The only modern things I saw are two grave sticks which are used to place across a grave before lowering the coffin, and a new lock on the south door. I picked up the old lock which was discarded 
and was laying on the floor. Going out the south door the first objects that met my eyes were the tombstones of Joseph Cox (my great great grandfather) who departed this life 17 April 1801 and by his side that of his wife - In memory of Mary Cox wife of Joseph Cox who departed this life Nov 241800 in the $86^{\text {th }}$ year of her age. [There follows a lengthy discussion of his ancestors' tombstones with quotes from inscriptions.] Without exception the form of tombstones was the slab with finish as executed. They are generally of marble but some are of blue stone or slate. The carvings on the latter are as distinct as the day they were chiseled. All in all, I have never seen an old grave yard in as good condition and kept as well as the Old Yellow Meeting House.

The main entrance as I stated is on the west end. About a hundred feet distant is a long shed (in a beautiful grove) in which those in attendance at church placed their horses. The grove contains immense white oaks in which bolts and staples to which the worshippers once attached their horses are fast being concealed by the growing bark. Many scars indicate that others have been completely covered. It is complimentary to know that although the doors of the building are never fastened, no vandal hands have ever mutilated any of the primitive furniture or building. ${ }^{38}$

Cox concluded his visit to the Old Yellow Meeting House by transcribing dozens of family tombstone inscriptions. "Altho it rained constantly while I was at the meeting house, my cousin held an umbrella over me..."

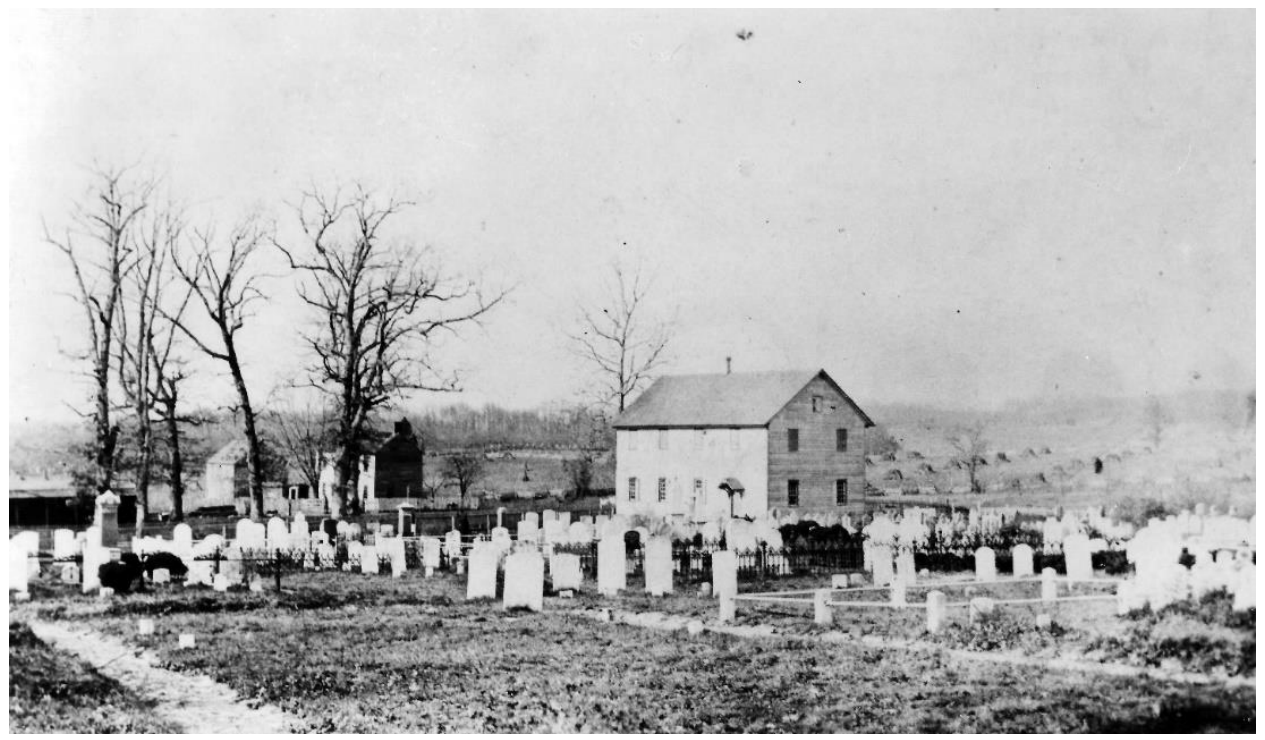

Perhaps the earliest known view of the Old Yellow Meeting House, depicting the property as described in 1896 by William V. Cox. Shown from right to left are the meeting house surrounded by its well-kept graveyard and open farmland, the parsonage, a barn, part of the grove of oak trees, and the horse sheds. Courtesy William T. Wentzien.

\footnotetext{
${ }^{38}$ Diary Letter of William V. Cox of Washington, D. C. on his visit to Cream Ridge, 4 to 7 September 1896. Copied when in possession of the late John Melton. Courtesy of Leslie and Peter Warwick, Middletown, NJ.
} 
A few additional newspaper notices provide context as to how the meeting house was used at the end of the nineteenth century and into the twentieth, besides funerals held for those individuals being interred in the graveyard that surrounds it. In August of 1885 "A camp meeting was held at the Yellow Meeting House, near Clarksburg, on Tuesday and Wednesday and will continue today (Thursday)." ${ }^{39}$ A 27 May 1897 notice indicated that "The Ladies' Aid Society of the Baptist church of Imlaystown, will hold a strawberry festival at Yellow meeting house on June $4^{\text {th }} . " 40$ But a nearly annual tradition that continues today began in 1913 - a reunion featuring speakers and a lunch. A large announcement in the Allentown Messenger informed the public that:

The Upper Freehold Baptist Church will hold a GRAND REUNION at the Old Yellow Meeting House, Red Valley, N. J. On Thursday, June 12, 1913. If stormy, the next day. Prominent speakers have been secured - Rev. W. A. Stanton, D. D., of Hightstown, Will speak at 11 a.m. Dr. Spencer, of Philadelphia, at 3 p.m. A Bountiful Dinner will be served at 40c. Ice Cream will be on sale. The proceeds will be used in improving the grounds and repairing the building. Come, and meet us at the old historic spot. ${ }^{41}$

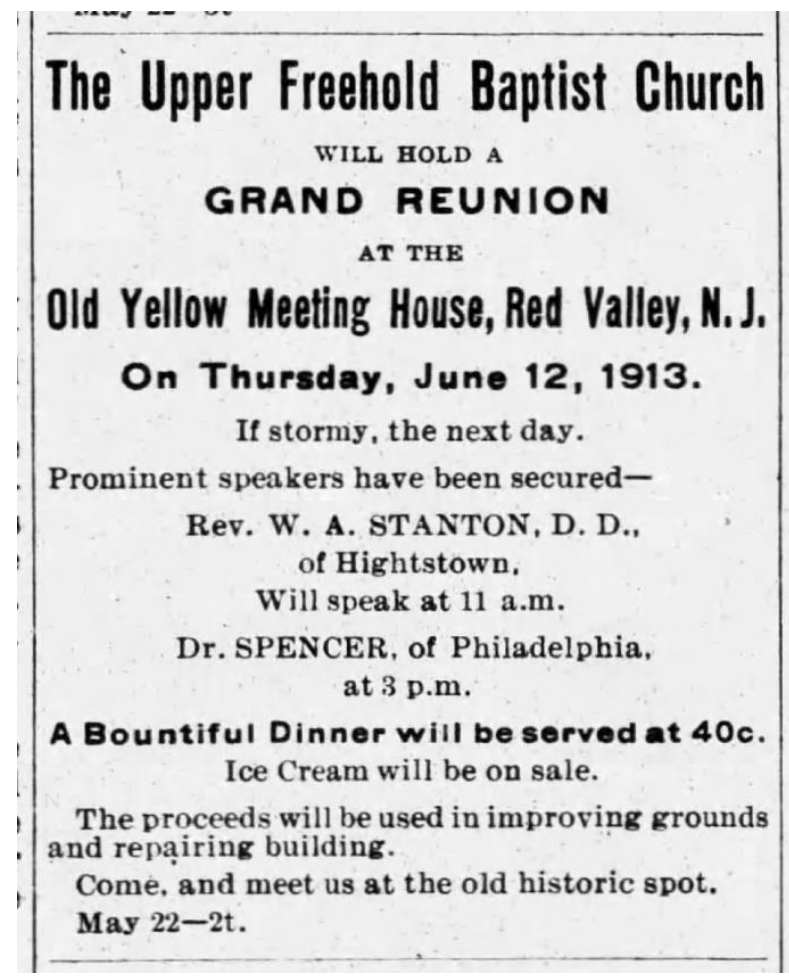

Advertisement for the first reunion held at the Old Yellow Meeting House on 12 June 1913. It has long been believed that these nearly annual events began in 1915. Allentown Messenger, 22 May 1913, courtesy of Newspapers.com.

\footnotetext{
${ }^{39}$ Monmouth Inquirer, 20 August 1885.

${ }^{40}$ Ibid, 27 May 1897.

${ }^{41}$ Allentown Messenger, 22 May 1913. The reunion was not held in 1941 due to the illness of its principal planners.
} 
Over the years the format changed very little, although the number of speakers was soon reduced to one. By 1929, an open air pavilion had been erected to the west of the meeting house so that the meal could be served regardless of the weather. ${ }^{42}$ Minutes of the congregation for 31 December 1928 note that:

The work of the Mens [sic] club should be called [to] attention at this time and this organization now stands ready to fall in line for any emergency. They have some money on hand for the erection of the roof of a permanent building out of doors for the harvest home suppers and other entertainment during the hot months, and the church should at once take such action as to make the ground available for such a purpose, and to begin the work so that it will be ready for the coming season. ${ }^{43}$

Attendance at the annual reunions averaged between 150 and 200 people or more for decades. These became major events that drew many of the old families of Upper Freehold together at least once a year, with some individuals traveling long distance to participate and to renew old acquaintances.

At the 1916 reunion, it was announced that "A new iron fence along the entire front will soon be erected, and large entrance gates, suspended from brick columns, will give the entire property an imposing appearance. It is expected that $\$ 750$ will be expended before the work planned is finished." ${ }^{44}$ This attractive installation commemorated the $150^{\text {th }}$ anniversary of the congregation's formal founding in 1766. In his annual report to the Trenton Baptist Association, the church clerk reported that "the improvement consisting of an iron fence facing the cemetery with seven large pillars built of yellow brick conform with the title Old Yellow Meeting House. The improvements are now nearing completion." 45 The iron fence and its signature yellow brick columns remain in place along the road frontage of the cemetery.

\footnotetext{
42 Trenton Evening Times, 27 July 1929. The pavilion has since been taken down.

${ }^{43}$ Upper Freehold Baptist Church, Minutes, 31 December 1928.

${ }^{44}$ Allentown Messenger, 29 June 1916.

${ }^{45}$ Upper Freehold Baptist Church, Minutes, 24 September 1916.
} 


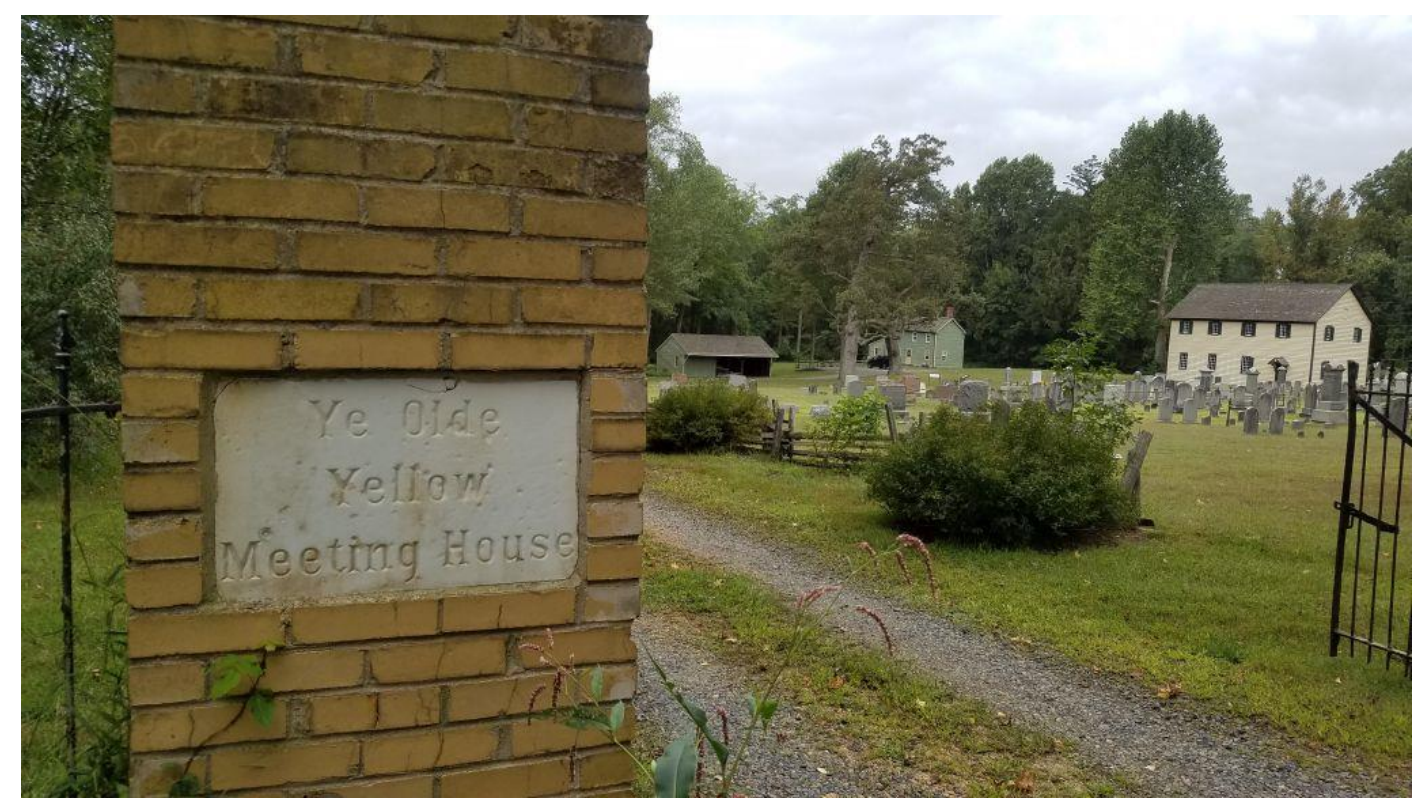

A recent view of the meeting house, cemetery, parsonage, and a modern utility building from the yellow brick and iron gate at the entrance to the property which was constructed in 1916. Courtesy gothambiketours.com.

Maintenance on the historic structure also received occasional notice in the local newspaper, the Allentown Messenger. On 3 July 1924, the paper noted that "The Old Yellow Meeting House, near Red Valley, has been much improved by a fresh coat of paint, which of course corresponds with the color mentioned. John W. Chasey did the work in a very able manner."46 More ambitious interior repairs were carried out two years later by contractor Chasey. "Ye Olde Yellow Meeting House, near Red Valley, is being renovated. The walls are being replastered where needed, and the interior is being freshly painted. John Chasey is looking after the work." 47

A lengthy illustrated feature article on the Old Yellow Meeting House appeared in the 30 July 1933 issue of the Trenton Evening Times. It recounted much of the lore and history of the place, and included the following description of the building:

One cannot call it a beautiful church. It is too severe, crude even in architectural style. It lacks the dignity and charm that age has given the old red brick Friends' Meeting House at Crosswicks, or the stateliness of Old Tennent with its spire towering into the blue. But it

\footnotetext{
${ }^{46}$ Allentown Messenger, 3 July 1924.

${ }^{47}$ Ibid, 7 October 1926.
} 
has a certain impressiveness that comes more from its religious atmosphere and its setting amid fertile farms and orchards.

Within it retains the spirit of a simpler age that is gone. The interior is equally as plain and unadorned as the outside. At one end is a pulpit that shows the wear and tear of the years. At the opposite end is a gallery, the width of the church. A curious stairway leads to it from the main body of the church with steps of old pine boards.

The benches are the old fashioned white type, with high stiff backs topped with mahogany rails. The seats are plain unpainted boards.

Time and weather have damaged the church inside and the walls particularly show the need for immediate repairs. ${ }^{48}$

Two interior illustrations of the Old Yellow Meeting House that accompanied the Trenton Evening Times article, even though very grainy, give important visual evidence of early pulpit furnishings and changes in pew arrangements. The view of the pulpit shows a simple Empire pedestal table in front of it that may well be a communion table dating from the 1836 rebuild of the meeting house. It is flanked by two simple klismos-form chairs of a type made by local Upper Freehold and Allentown chairmakers in the nineteenth century. Careful study of the image concludes that they are not a matched pair although similar. The reading desk is covered by a pillow ornamented with corner tassels as described in 1896 by William V. Cox. The other view looking from the pulpit toward the west gallery indicates that alterations to the early pew plan had been made by 1933. Two short pews filled in the space under the front edge of the gallery where a wood stove once stood. A third short pew can be seen stored at an angle against the rear wall of the gallery. These three pews are in all likelihood those removed at some point from the left or north side of the pulpit. A long pew that matches those on the first floor can also be seen on the north side of the gallery just behind the rail, situated on the flat floor area in front of the benches.

\footnotetext{
${ }^{48}$ Trenton Evening Times, 30 July 1933.
} 


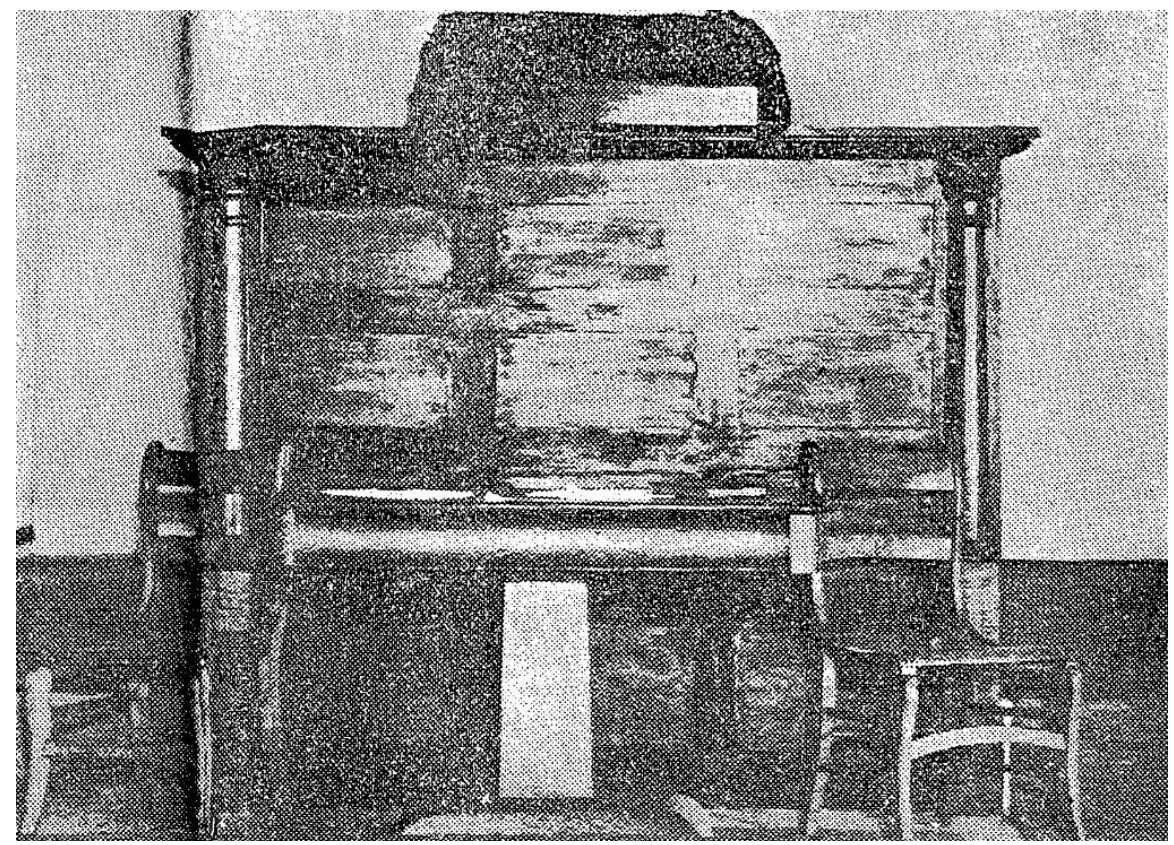

The view of the Old Yellow Meeting House pulpit that accompanied the 1933 article in the Trenton Evening Times showed an Empire pedestal table and two nineteenth century chairs that no doubt formed the early pulpit platform furniture. Courtesy Friends Archive.

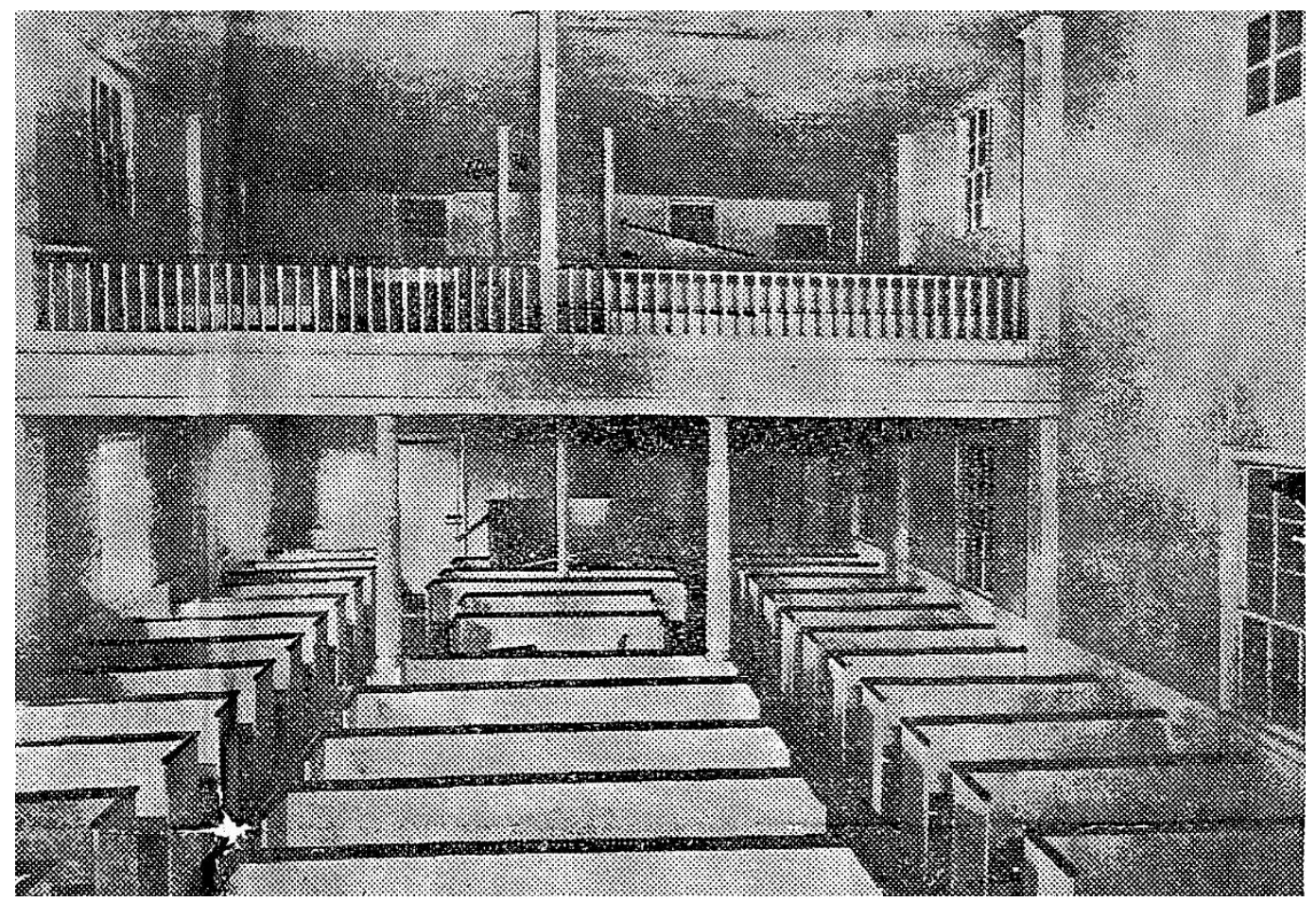

The interior view from the same newspaper article provides visual evidence that changes to the early pew plan had been made by that time. Two short pews in the center filled the space once occupied by a wood stove. Note also a long pew just behind the gallery rail on the right that matches those on the first floor, and a third short pew stored at an angle against the back wall of the gallery. Courtesy Friends Archive. 
By the 1970s, it was becoming increasingly difficult for the Upper Freehold Baptist Church to continue its stewardship alone of the Old Yellow Meeting House due to declining membership. At the same time, wider community interest in the venerable building began to develop that resulted in the formation of an independent Friends support organization.

The Friends of the Old Yellow Meeting House Inc began in 1974 as a spin-off of the Environmental Commission of Upper Freehold Township, Ms. [Elizabeth G. Wright] Meirs said. The commission did a natural resources inventory of the township that included both land, water and historical resources, Ms. Meirs said. She said they knew of the Old Yellow Meeting House as an "old thing in the township" and discovered it was owned by the Upper Freehold Baptist Church. "It was deteriorated and not regularly kept," said Ms. Meirs. "We took it on as a concern." 49

One of the first tasks undertaken by the Friends was to place the meeting house on the New Jersey State and National Registers of Historic Places. The nomination form, dated 20 March 1975, was prepared by Helen S. Polhemus, a member of the Upper Freehold Baptist Church, with assistance from David N. Poinsett, then Supervisor of the Historic Sites Section of the New Jersey Department of Environmental Protection. It ranks among the better prepared New Jersey nominations submitted in the years leading up to the American Bicentennial, even if critical dates were not at that time known. The Old Yellow Meeting House was accordingly entered onto the National Register on 21 April 1975.

Simultaneously with the preparation of the Register nomination, the Friends began to investigate the condition of the meeting house. On 4 January and 15 January 1975, William H. Short of Short \& Ford, historic architects of Princeton, made two site visits in company with several interested members of the Friends. His remarks set the initial tone for the organization:

The Olde Yellow Meeting House is important and must be preserved because it is the oldest extant Baptist church building in the State of New Jersey and the third oldest in the nation - but even more - because it is in its original setting, in its original form, and in remarkably good condition. It is a beautiful and simple interior.

\footnotetext{
${ }^{49}$ Messenger-Press, 27 July 2000.
} 
Although this report does not discuss the site, it is essential to keep enough undisturbed land around the buildings and the cemetery to maintain the rural feeling. This was and still is a place in the country to which people gather to worship, socialize and bury the departed. That spirit must be kept.

The following proposals are made with the assumption that the form and appearance will not be changed or added to, except for the possibility of heating elements and lighting fixtures. We recommend that in doing further maintenance and repair, the dimensions and details of the original materials should be copied precisely. This type of work costs more than using stock material, but it is vital for maintaining the authentic quality of the building.

We think that a way to assure the preservation of the Olde Yellow Meeting House is to give it more active use and better surveillance. We understand that others are preparing proposals for intended uses and for security provisions. ${ }^{50}$

Short's report then outlined work to be considered, including maintenance and repair of the structure and exterior, as well as installation of a heating system, electric lighting, insulation, and toilet facilities. He also made general comments on rehabilitation of the adjoining parsonage so that onsite caretakers could be accommodated to improve security.

At a meeting held on 9 July 1975, the Friends voted to incorporate as a non-profit, nonsectarian organization dedicated to the "preservation, care and appropriate use" of the meeting house and its adjacent cemetery. Shortly thereafter, a formal membership drive sought to broaden its base of support among those individuals who in one way or another had actively participated in the association's work to that date, or who had expressed interest in doing so. ${ }^{51}$ The following year, the Friends were awarded a Historic Preservation Grant of \$5,700 from an annual allotment given to New Jersey by the National Park Service. Actual payment would be contingent on submitting appropriate work plans and specifications to the State, and on furnishing matching funds. The grant was intended to be used for basic work on the "studs, doors, clapboards, sills of the Meeting House, plus painting the exterior and interior." 52 It turned out that not all of these

\footnotetext{
${ }^{50}$ William H. Short, Report on the Olde Yellow Meeting House Buildings, 15 January 1975. Friends Archive.

${ }^{51}$ Messenger-Press, 26 June 1975.

${ }^{52}$ Ibid, 13 May 1976.
} 
goals would be achieved for another fifteen years, and after the expenditure of much more money.

The Friends learned early on that the care and maintenance of a two-hundred-year-old structure was far more complicated and costly than anticipated.

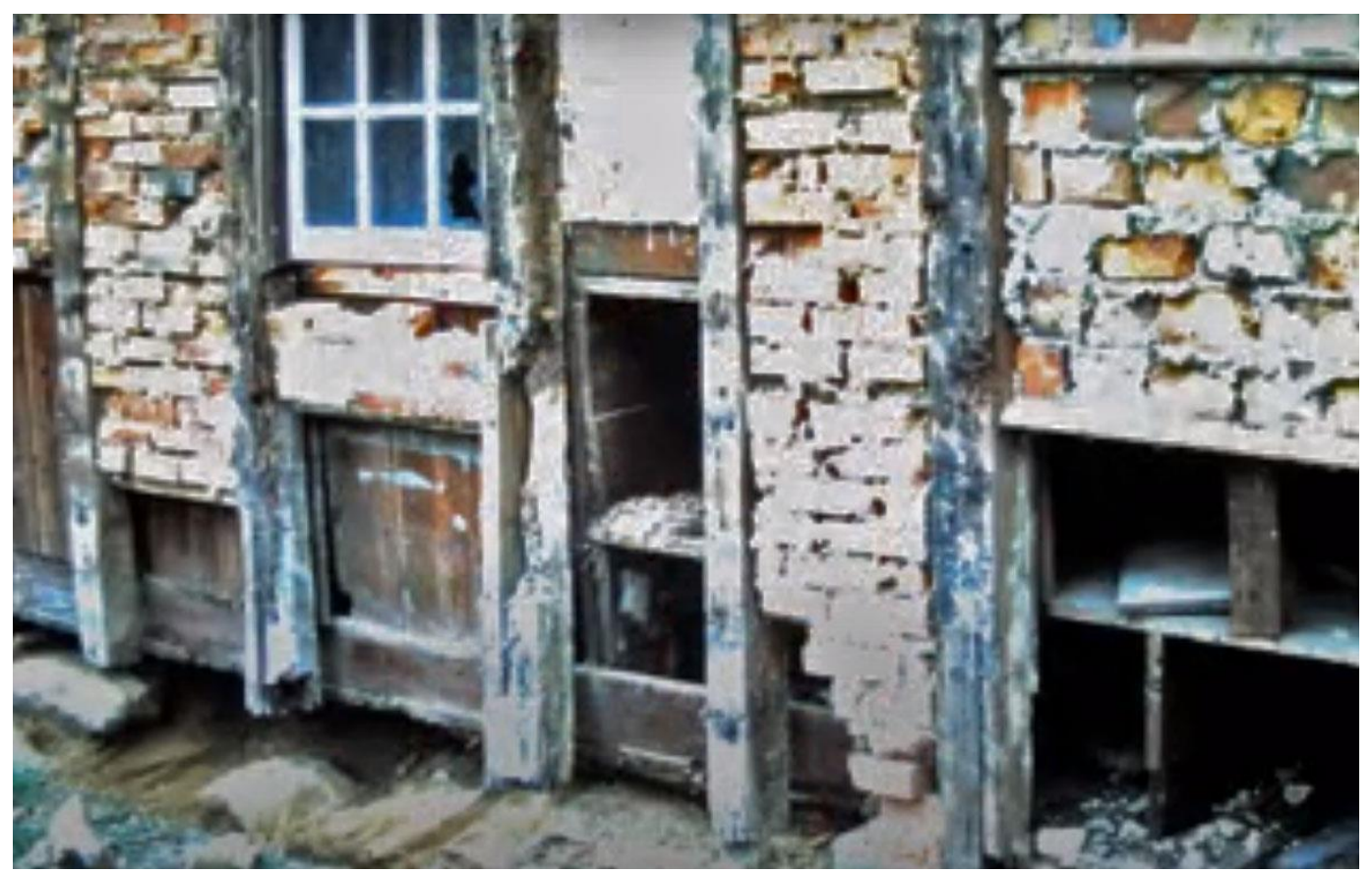

Severe deterioration of the sills, wall studs and brick nogging was discovered in the south corner of the east elevation in 1977/78. The back of the raised pulpit platform can be seen on the right. Courtesy OYMH Slide Show.

The first phase of work on Old Yellow Meeting began in October of 1977, and continued into 1978. It involved stabilization of the foundations and the exterior, including extensive work on the entire east elevation. Two sheets of detailed drawings for the project had been drawn up in the fall of 1976 by Michael Mills of Short \& Ford. The first depicted the framing of the first floor. It showed that the floor joists of early section connected to a summer beam in the center which ran the full length of the building. Annotations on the drawing made recommendations for repair. Floor plans accompanied the framing schematic. Changes to the pew arrangements on the first floor included the three short pews removed years earlier from the north side of the pulpit. The two short pews in the center of the floor shown in the 1933 newspaper illustration had by this time also been 
removed, and replaced by the long pew from the west gallery. It was longer than the other center pews, so projected into both aisles. The second sheet contained drawings of all four exterior elevations of the meeting house, again with annotations that recommended repairs.

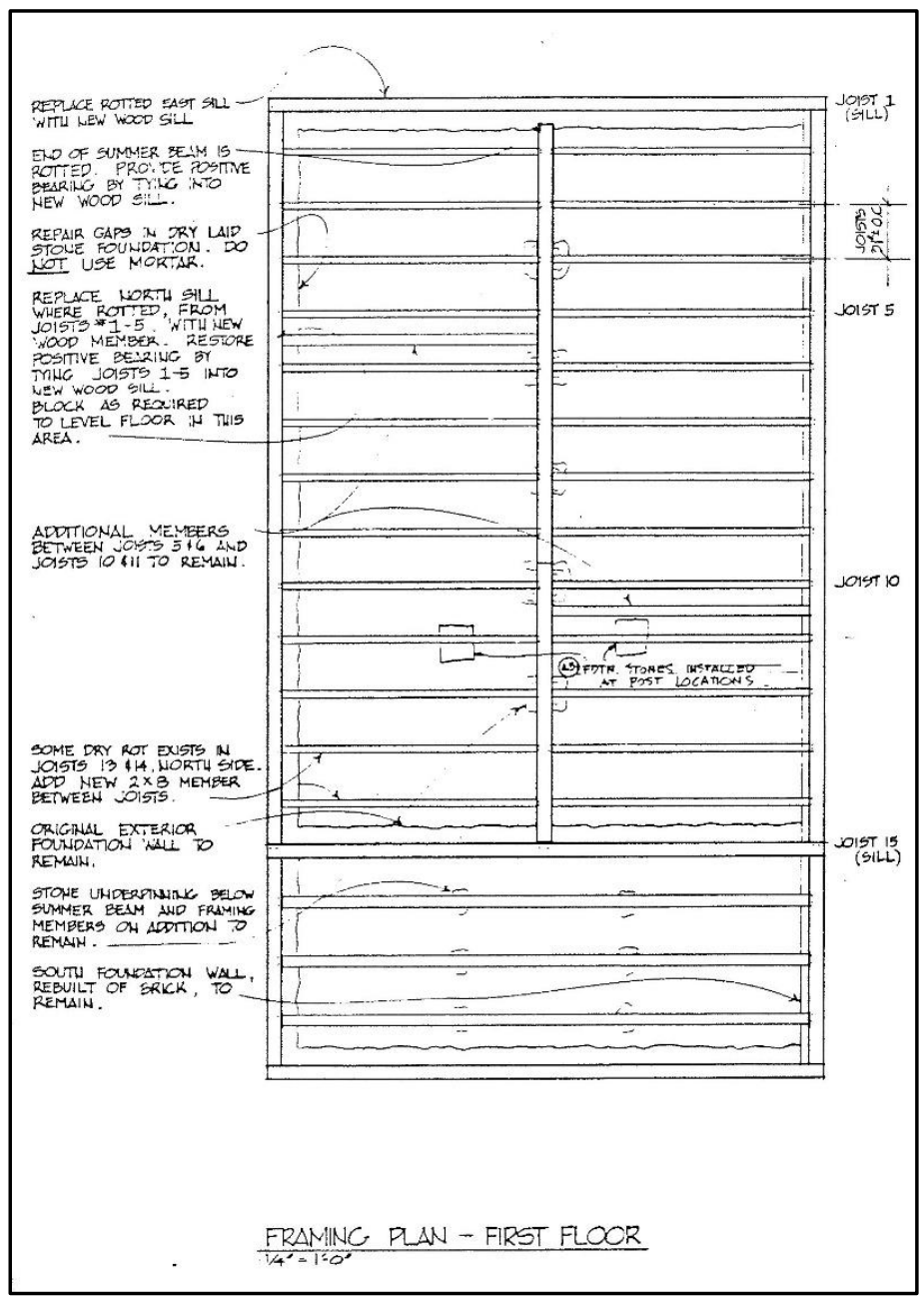

The Short \& Ford first floor framing diagram showed a center summer beam running the full length of the early section of the meeting house. Recommendations for repair of the framing were noted in the left margin. Courtesy Friends Archive. 


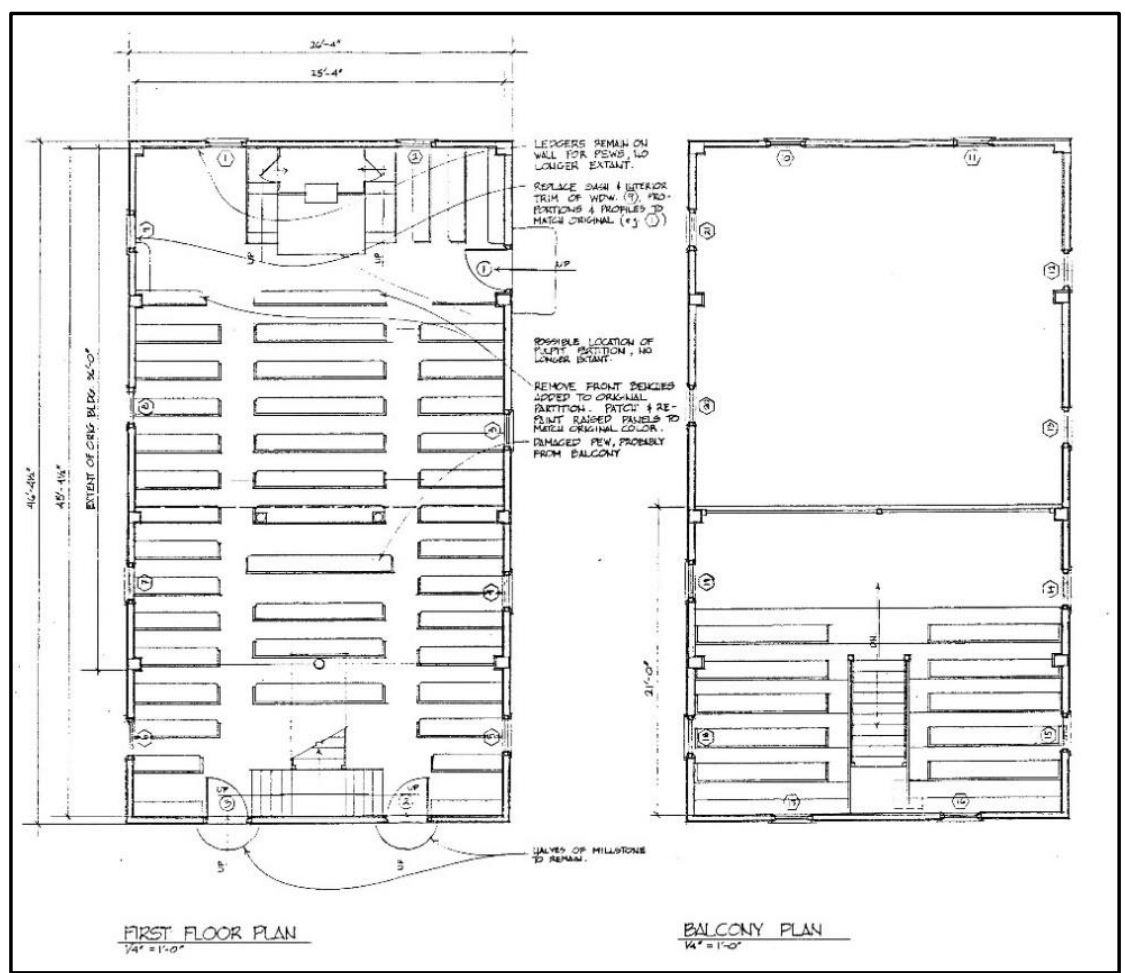

The Short \& Ford floor plan drawings documented the pew arrangements as they existed in 1976. The two short pews in the center had by then been replaced by the long pew from the west gallery. It has since been removed and placed in storage. Courtesy Friends Archive.

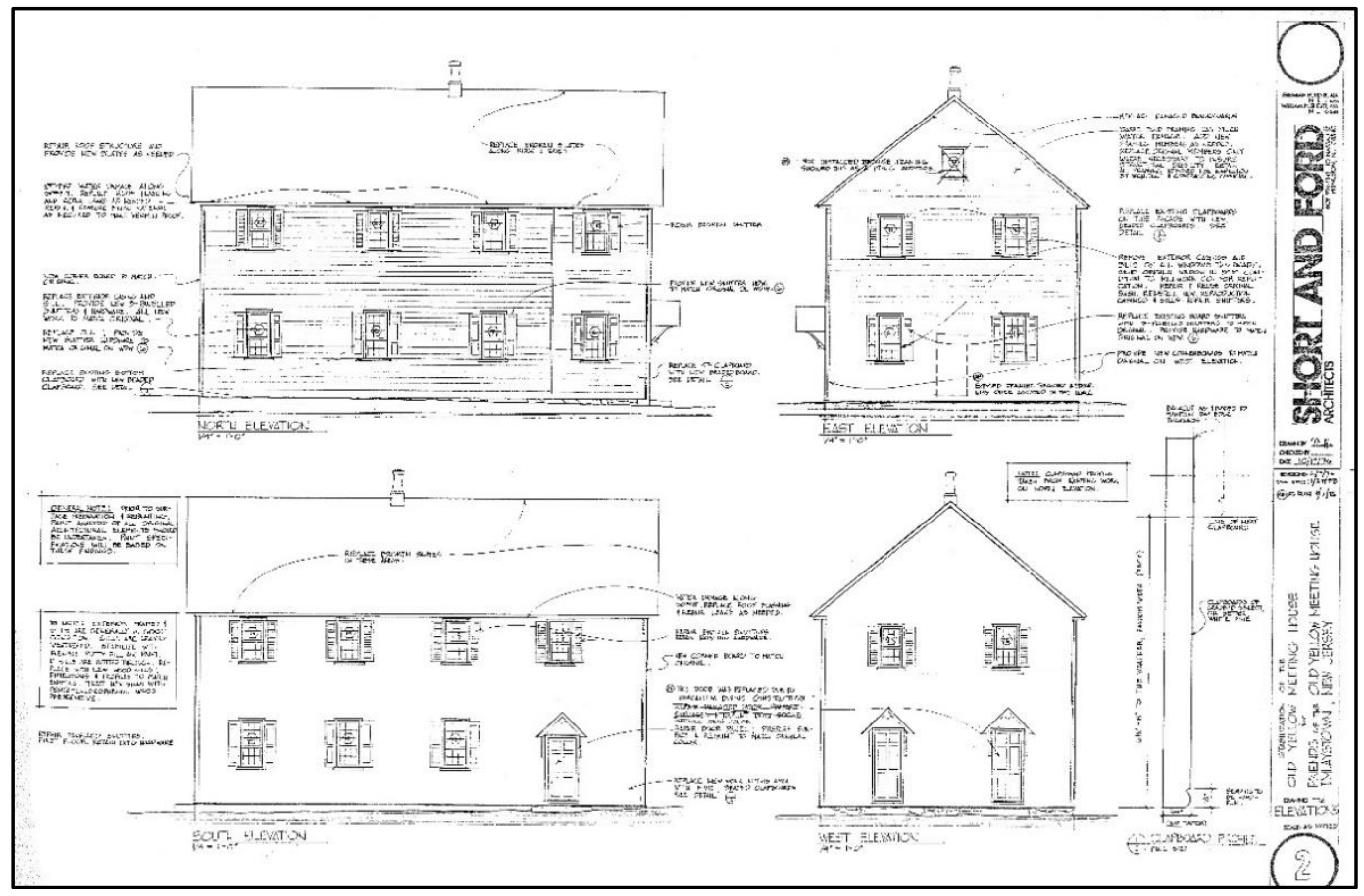

Elevation drawings for the exterior of the meeting house contained many recommendations for repair in order to secure the building from further water damage. Courtesy Friends Archive. 
It was found after work commenced that the northeast corner had sunk in spite of being pieced out once before. Extensive rot was also encountered, involving the sills and lower ends of the studs. As part of the repairs, the entire east wall was stripped of its weather boards, which were then replaced with replicated beaded siding. And slowly, information about the changes wrought on the building emerged. For example,

a professional paint analysis reveals that the Old YELLOW Meeting House - while originally and usually yellow - has also had intervals of being painted gray or white: and the present dark trim dates from the Victorian period. ${ }^{53}$

This was also the time when the former existence of a door in the east elevation was discovered.

Membership in the Friends had increased by then to 380 individuals and families. Work on the interior of the meeting house was postponed to a later restoration phase.

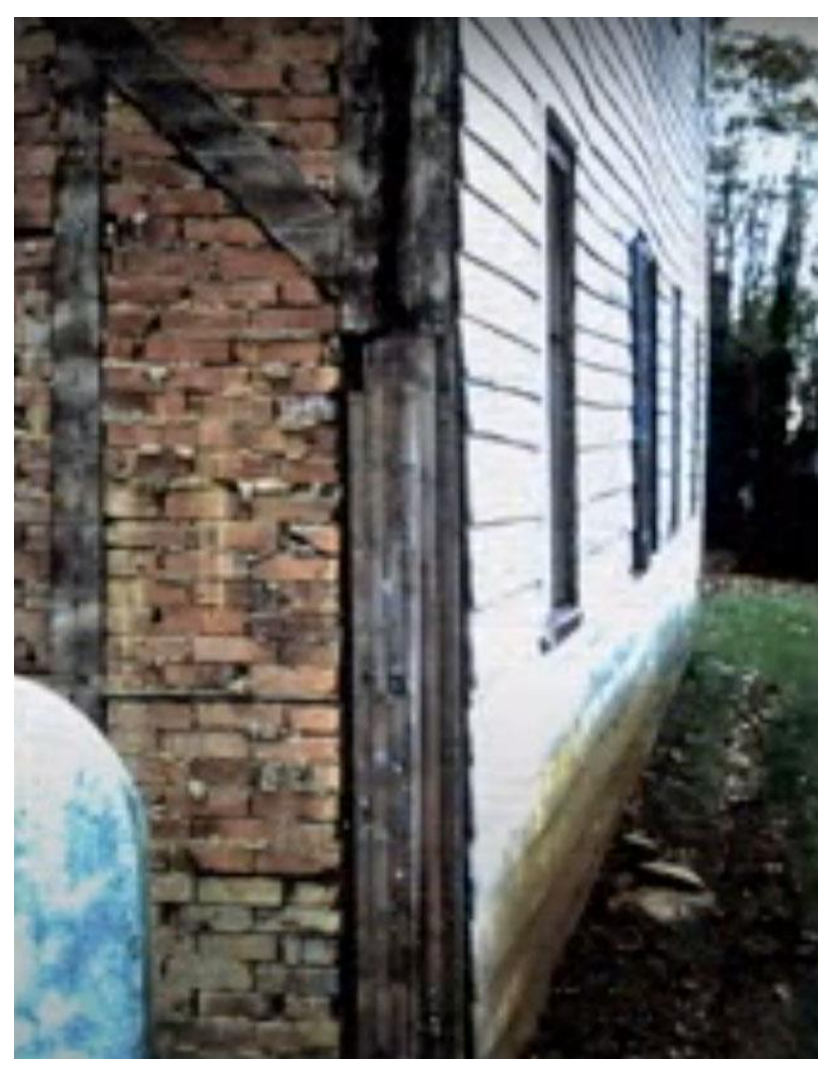

An old repair of the northeast corner post exposed in 1977/78, pieced out roughly six feet. Courtesy OYMH Slide Show.

${ }^{53}$ Ibid, 18 May 1978. 
The next major project on the site of the Old Yellow Meeting House was the rehabilitation of a derelict parsonage structure located west of the meeting house. Dating in part from the late eighteenth century and enlarged at a later time, the parsonage was to be used as an onsite residence once again as vandalism in the graveyard and on the structures had become an increasing concern. Work on the building commenced in 1984. By the following year, the Friends had so far raised $\$ 60,000$ toward restoration of it and the meeting house, a significant accomplishment for the allvolunteer group. ${ }^{54}$ But work on the interior of the sanctuary remained elusive, and was put off again.

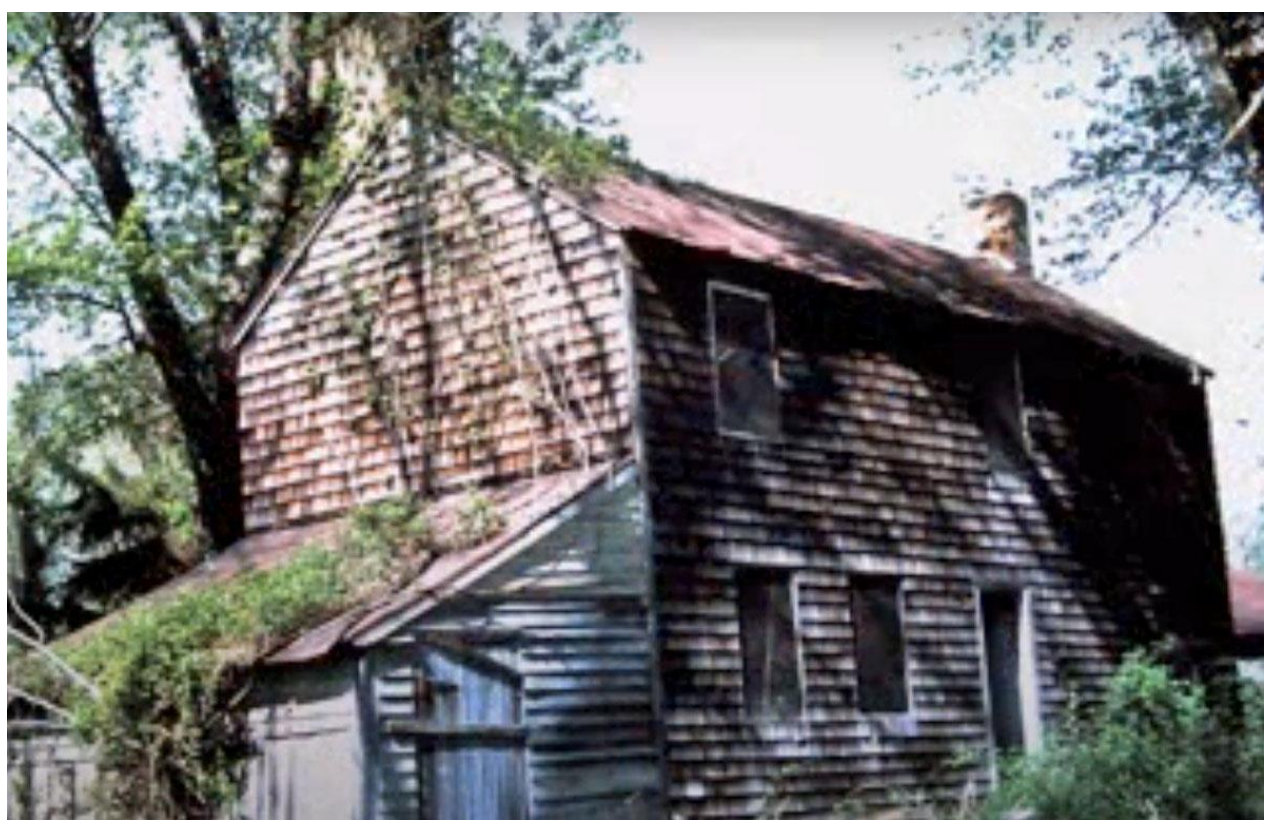

The parsonage to the west of the meeting house had become very derelict by the 1970s. It had not been occupied for some years. Courtesy OYMH Slide Show.

${ }^{54}$ Ibid, 2 August 1984. 


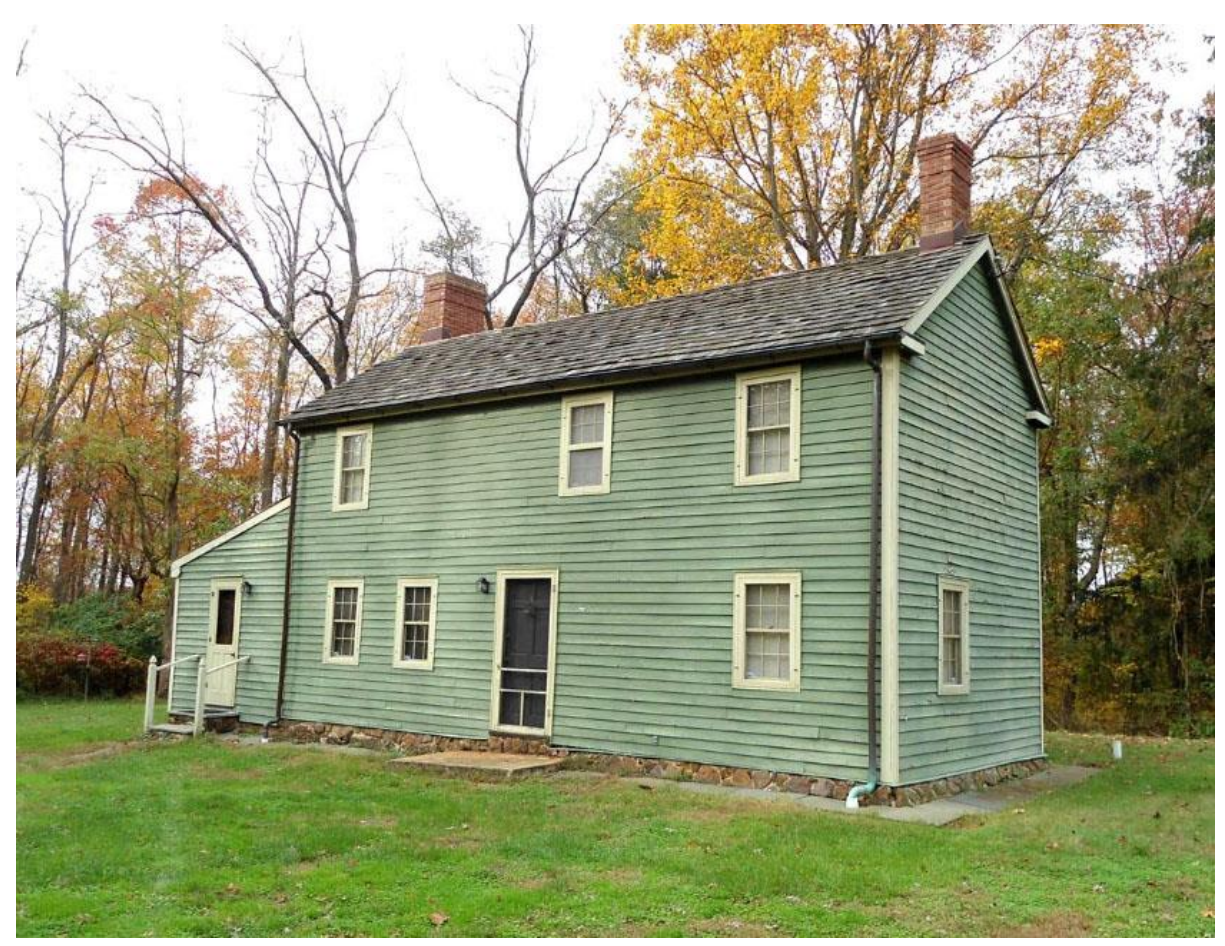

The parsonage as it has appeared since renovation in 1984. The window over the entrance was moved to the right so that a bathroom could be installed in that area of the second floor. Courtesy The History Girl as posted on Pinterest.

The financial picture of the Friends changed dramatically in 1987 with the receipt of a $\$ 150,000$ cash bequest from Teresa Evernham Pardoe (1906 - 1987), a former member. Announcement of the gift was made at the annual reunion that July. The Friends, along with other organizations in Allentown, were "shocked and pleased after learning about significant bequests from the late Mrs. Pardoe, whose family at one point lived in the Upper Freehold area." 55 While it would be two years before the cash was actually received, the Friends engaged Short \& Ford again in 1988 to prepare an extensive assessment of the meeting house in anticipation of pressing forward with the long-desired interior work.

The purpose of the Short \& Ford report, dated September 1988, was "to investigate the existing conditions of this building as they are in the summer of 1988 to determine: a) how far

${ }^{55}$ Ibid, 30 July 1987. 
deterioration has progressed, b) what are the causes of the deterioration and c) what remedial measures should be taken." It pointed out in the introduction that some areas would require further physical investigation to fully evaluate structural conditions. The report then stated that:

This document is a report, not a specification: it lists defects found but does not give detailed instructions for remedying them. Builders should not be expected to quote for or carry out the specialized work required without further guidance. They should, instead, be provided with detailed drawings and a proper specification. Even small errors in workmanship or materials could be structurally or historically disastrous for this building. ${ }^{56}$

The Short \& Ford report outlined in detail problems and recommendations for the structural aspects of the meeting house, including the roof, ceiling, floors, sills and wall framing, and foundations. It then addressed moisture protection, building systems such as heat, electrical, and fire suppression, as well as exterior and interior finishes. The text ended with an outline of restoration priorities, and with appendices containing a separate report from a consulting structural engineer, and the annotated drawings prepared by the firm in 1976.

Work on the Old Yellow Meeting House commenced soon after the Pardoe bequest had been received in 1989. The Friends did not engage Short \& Ford for additional drawings and specifications or to oversee construction. Instead, they elected to proceed on their own in spite of advice to the contrary outlined in the Short \& Ford report. ${ }^{57}$ Many of the recommendations made by the architects were not followed. Selected examples included:

- Replace the deteriorated slate roof with new slate. Because the existing roof was of the same vintage as the chimney pot and slated hoods over the entrances (1877), and its weight had caused no apparent stress on the roof framing, Short \& Ford recommended replacement slate for historical appropriateness, fire rating, durability, and cost in the long run. The labor costs for installation were also roughly the same as wood shingles, which in the end were chosen instead of slate. During roof replacement, the chimney pot was removed from the building, while the doorway hoods were covered with shingles. This resulted in a combination of exterior features that never existed historically.

\footnotetext{
56 Short \& Ford Architects, Old Yellow Meeting House: Report on Existing Conditions, September 1988. Friends Archive.

${ }^{57}$ Personal Communication, Michael Mills to Joseph W. Hammond, 13 October 2020.
} 
- Preserve as much as possible of the interior plaster with its history of paint finishes. Short $\&$ Ford also recommended removal of old sheet rock patches, and investigation into the cause of significant deformation or sagging toward the middle of the plaster ceiling, which they viewed as an urgent life safety issue. In the end, most early plaster was removed, with the possible exception of some areas in the west gallery.

- Add an on-grade brick gutter at the drip line of the eaves and provide for runoff. Much splashback had occurred on the lower portion of the meeting house walls, causing extensive rot to the sills, floor joist ends, wall studs, and exterior weather boards. This important step in controlling moisture damage was never undertaken.

- Install a forced air heating system to minimize condensation, with a boiler or furnace located in a separate utility structure to reduce fire risk. The structure and finishes of the meeting house had suffered significant damage for decades due to large seasonal swings of temperature and humidity. The building could also not be used in winter. To date, the meeting house has not been provided with heat.

As part of the conditions report, Short \& Ford also pointed out that the new beaded weather boards installed on the east elevation in 1977/78 exhibited peeling paint and mildew. Beneath the siding the contractor had placed a layer of asphalt impregnated building paper. The weather boards were also not back-primed. Building paper had not been specified on the 1976 drawings and should not have been installed. Humidity conditions in the meeting house apparently caused a dew point within the wall because of the paper that was resulting in deterioration after only ten years. Short \& Ford recommended that the weather boards be taken off the entire east gable end, the building paper be removed, and the siding be dried out, back-primed, and reinstalled. Had there been onsite supervision by the architects during the $1977 / 78$ work, this recommendation would not have been necessary.

A portion of the Pardoe bequest could have been used by the Friends to engage a professional historic architecture consulting firm for the preparation of a formal Historic Structure Report or Preservation Plan to help guide anticipated work on the meeting house. Such a document, broader and more detailed in scope than the 1988 condition report, would have assured that applicable restoration standards, methods, and materials would be employed. Instead, the Friends 
launched into the next phase of the project with enthusiasm but largely on their own. That decision resulted in a well-intentioned but historically inconsistent restoration project.

The annual Old Yellow Meeting House reunion held on 28 July 1991 served to showcase the finished renovations on the landmark historic structure. At long last, it also marked the completion of goals set in 1976 to assure the preservation of the building. Announcement of the event stated the following:

The building, dating back to 1737 , has been completely renovated, and resembles as closely as possible the structure as it stood in the 1700s. The outside is painted the original yellow color with slate green trim, while the inside is lilac, highlighting the white and brown wooden pews. An unusual feature of the OYMH is the extremely high pulpit area. ${ }^{58}$

There were several problems with this statement. First, the meeting house extension and alterations of 1836 changed the character of the building entirely, leaving virtually no trace of its eighteenthcentury appearance. Second, the exterior paint analysis carried out in the 1970s dated the dark green trim as Victorian. Third, the Greek Revival pulpit, installed as part of the 1836 renovation, although raised, is not excessively elevated by eighteenth century standards of high pulpits perhaps surmounted by a sounding board.

Interpretation of the Old Yellow Meeting House as an eighteenth-century building was not entirely the fault of the Friends. The 1988 Short \& Ford report stated that "The date of construction of the Old Yellow Meeting House has traditionally been accepted as 1737 . . Most of the exterior and interior elements, including doors, pews, windows, hardware, corner boards, and remaining clapboards date from the late eighteenth century." The report also noted that "No attempt was made to document the house historically, beyond the most general of observations. The approach taken was that the existing building elements were to be conserved wherever possible, and that a comprehensive historical study could be done at any time in the future." If even a cursory review

\footnotetext{
${ }^{58}$ Messenger-Press, 18 July 1991.
} 
of the Upper Freehold Baptist Church minutes had been undertaken, it would have been discovered that the expansion and renovation of the meeting house took place in 1836 . The very simple and conservative nature of the building's exterior and interior details misled the architects into thinking that the rebuild took place about $1780 .{ }^{59}$

An especially troublesome part of the 1990/91 work was the color selected for the plaster walls, called "lilac" in the newspaper announcement but really a shade of lavender. Dampness had been causing difficulty with the interior wall finishes of the meeting house for many years, as pointed out in the 1933 Trenton Evening Times article quoted above, when it was noted that the walls needed immediate attention. And that was only seven years after the plaster had been patched and repainted by contractor John Chasey. For decades thereafter, paint continued to peel off the plaster, often in large pieces. By the 1970s, one of the main tasks of preparing the meeting house for the annual reunion involved scraping loose paint that could be reached, and sweeping up the flakes that had fallen on the pews and floors.

\footnotetext{
${ }^{59}$ Short \& Ford Architects, Op. Cit., [1 - 4].
} 

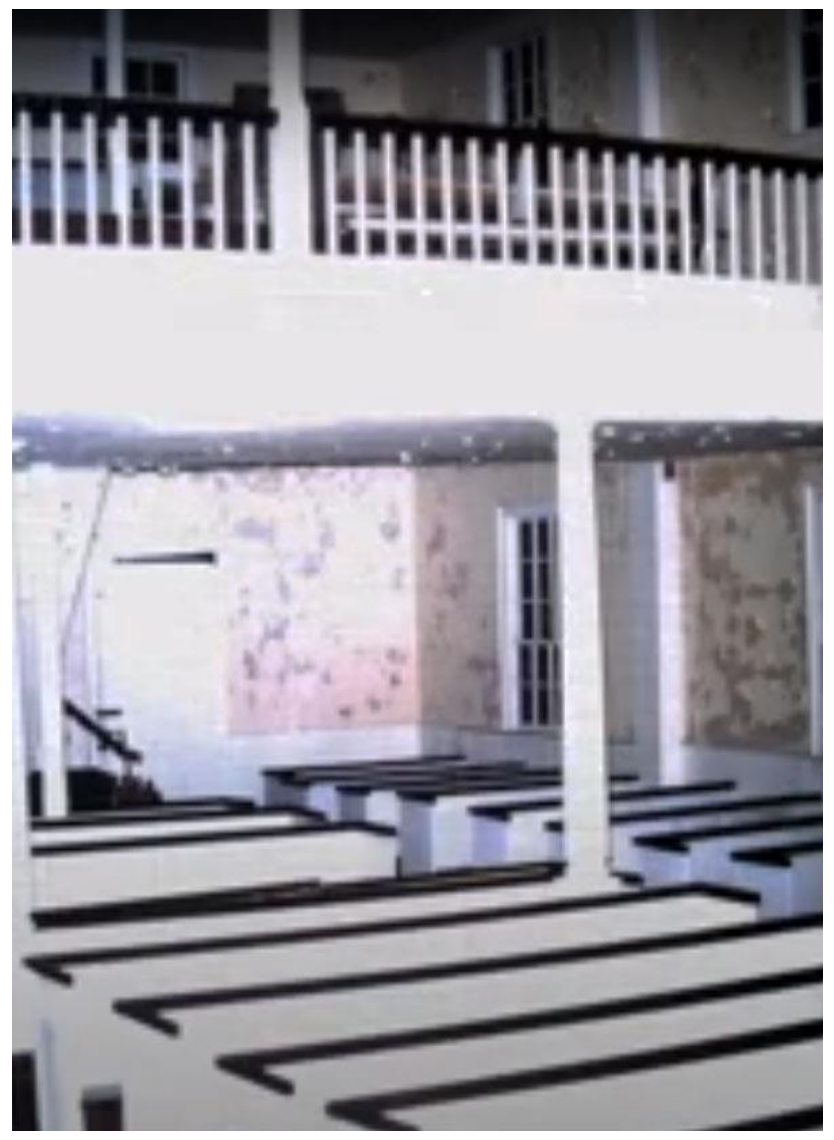

The west end of the meeting house interior before rehabilitation. Note the deteriorated condition of the paint finishes on the plaster walls and ceiling under the gallery, which had peeled extensively. OYMH Slide Show.

When exterior work on the meeting house was carried out in 1978, professional paint analysis documented the sequence of its several colors applied over time. A similar study of the interior finishes took place in 1981 in anticipation that work would at some point be undertaken inside the building. Four layers of paint were identified - lavender, beige, yellow ochre, and pale yellow. The analyst listed the colors in that order in her final report, indicating that they were in sequence from bottom to top, with lavender being the original color (meaning post-1836 rebuild). Sample paint chips that accompanied the report matched the four colors to those closest in the 1977 edition of the Moor-O-Matic Universal Color System. Chemical analysis suggested that the excessive peeling of the interior paint finishes had been caused by a latex or vinyl-based coat 
applied over at least one but probably three layers of calcimine paints. ${ }^{60}$ Acrylic or vinyl-based paints were not commercially available until the 1950s. Even so, the 1926 refreshing of the meeting house interior failed quickly, as noted in the 1933 Trenton Evening Times article.

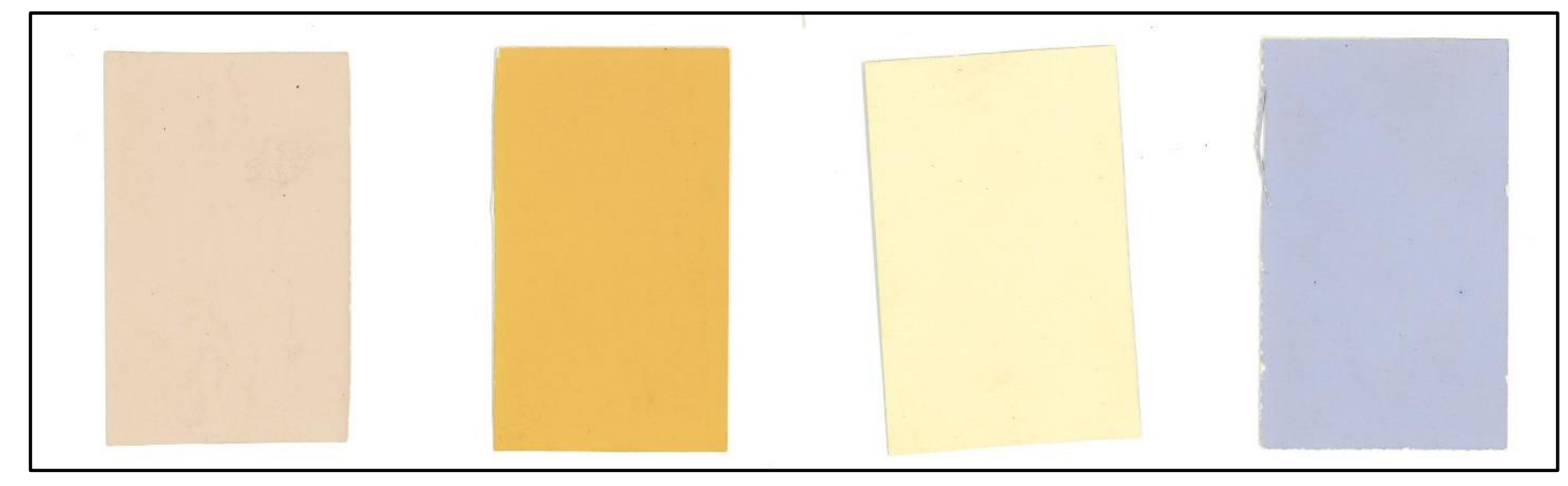

Sample color chips provided in 1981 as part of a professional paint analysis of the meeting house interior. Courtesy Friends Archive.

Examination of sample paint peelings and the plaster surfaces by this author and others revealed that following the 1836 rebuild of the meeting house the plastered parts of the walls were at first whitewashed. ${ }^{61}$ This was not mentioned in the professional analysis report. On top of one or more layers of it, at some point a very intense yellow ochre paint about the color of dark yellow mustard was applied to the walls. This was followed by a light blue, which William V. Cox described in 1896 as a "blue tint." When the interior of the meeting house was refreshed in 1926, a pale yellow was selected which shows as the top layer in color images taken in building in the 1970s, two of which are included above in this article. The blue coat can also be seen in those images where the yellow has peeled off. In light of this visual evidence, the correct sequence of paint colors from oldest to newest should be beige, yellow ochre, light blue (known to be on the walls in 1896 that was definitely on top of the yellow ochre), and pale yellow probably from 1926,

\footnotetext{
${ }^{60}$ Leslie Lord, Report on the Analysis of Interior Finishes at the Old Yellow Meeting House, Imlaystown, New Jersey, 2 July 1981, with follow up correspondence on 7 July 1981. Friends Archive. The cause of failure may actually have been an underlying layer of whitewash not discussed in the Lord report, combined with dampness.

${ }^{61}$ William H. Short, Op. Cit., 3. Friends Archive.
} 
all over a base of whitewash. ${ }^{62}$ Unfortunately, most if not all early plaster with its important paint evidence was removed during the interior rehabilitation. To this writer's knowledge, no sample paint chips were retained for future study. ${ }^{63}$

Continued declining membership in all mainline religious organizations impacted the Upper Freehold Baptist Church to the point that the congregation was dissolved in 2014. This brought to an end almost three centuries of its ministry to the community. The assets of the church were subsequently dispersed. The 1904 house of worship in Imlaystown was sold in 2016 for conversion into a private residence. The owner has retained much of its original character,

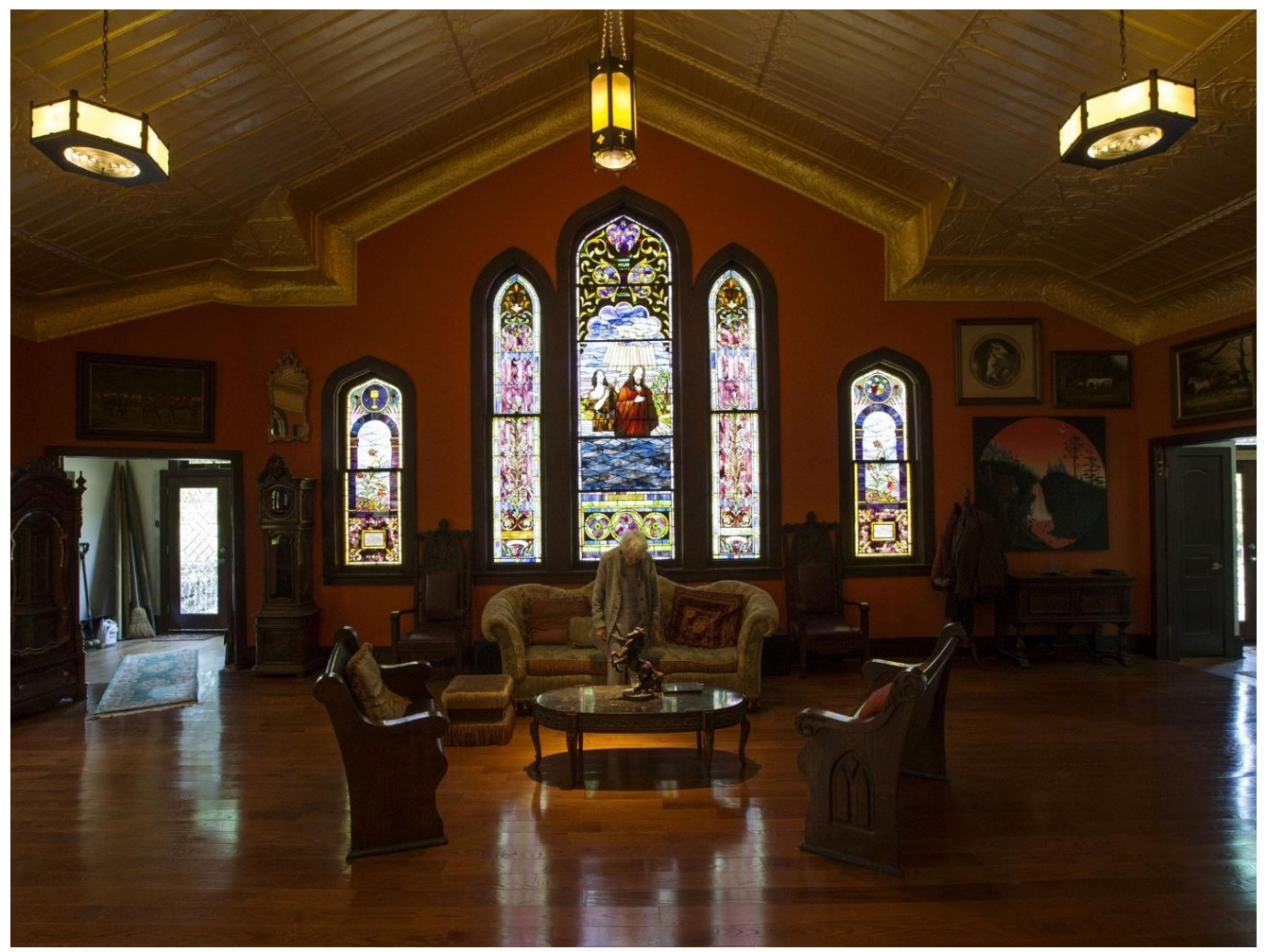

After being sold in 2016, the Upper Freehold Baptist Church was converted into a private residence. Original features retained include an open floor plan, stained glass, and tin ceiling. Courtesy Doug Hood photo, Asbury Park Press.

\footnotetext{
${ }^{62}$ When the meeting house interior requires future repainting, consideration should be given to selecting a historically correct beige or pale yellow to replace the present lavender. Also, exterior trim should be redone in its pre-Victorian paint color that existed after the building reached its 1836 final form.

${ }^{63}$ During a site visit to the meeting house on 3 August 2020, it was observed that some areas of early plaster may remain in the west gallery.
} 
inside and out. ${ }^{64}$ Church records were deposited with the Allentown Public Library, where they presently await cataloging. The Old Yellow Meeting House property with the graveyard, still consisting of 17 of its original 26 acres from 1720, was conveyed to the Friends of Old Yellow Meeting House, Inc. ${ }^{65}$ With critical help from this non-sectarian, non-profit group, the annual reunions begun in 1913 continued to be held into the twenty-first century even as the Baptist members were less and less able to organize it on their own.

The future of the Old Yellow Meeting House is secure for the moment. The property on which it sits is presently surrounded on three sides by acreage now in the New Jersey Farmland Preservation Program, thus assuring that its picturesque rural environment will remain mostly intact. However, declines in Friends membership, deaths of key supporters, and a general

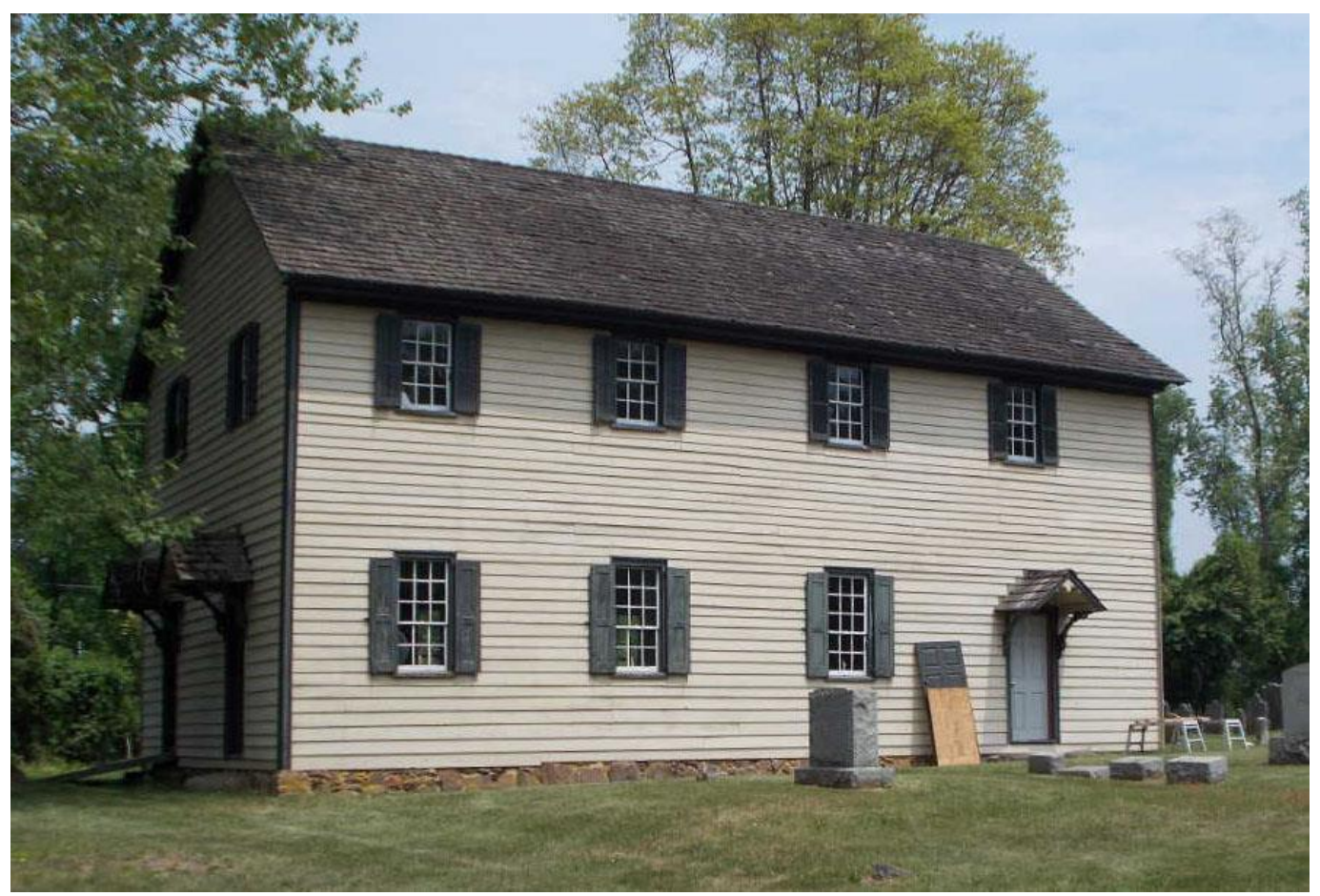

The Old Yellow Meeting House as it appears today. Note that one of the early paneled doors on the right has been removed and its replicated replacement installed but not yet painted. Courtesy Nancy Tindall.

\footnotetext{
${ }^{64}$ Asbury Park Press, 30 January 2017.

${ }^{65}$ Upper Freehold Township Tax Map, Sheet 9, Block 16, Lot 6, as of 31 December 2013. The property then consisted of 16.93 acres. The remaining 9 acres of 1720 are subject to a deed overlap with an abutter. A resurvey conducted in 2019 remeasured the property as 17.3 acres, more or less.
} 
public loss of interest in history make the long-term picture less certain. The Old Yellow Meeting House has survived lean times in its past. A consortium of individuals, organizations and government agencies is presently trying to find the right combination of involvement and funding to keep the oldest Baptist meeting house in New Jersey in good order, and with a community purpose for the foreseeable future.

As a major first step, the Friends on 13 November 2019 entered into a Conservation Deed of Easement and Right of First Refusal Option Agreement with the County of Monmouth for the Old Yellow Meeting House property. This detailed eleven-page document with appendices defines the rights and obligations of the Friends and the County with regard to the buildings and grounds. It acknowledges that "the Property stands as the only remaining example of early traditional meeting house form in Monmouth County, illustrates aesthetics of design and setting, and possesses a high degree of integrity of materials and workmanship..." The agreement continued by stating that the "Grantor and Grantee recognize the architectural, historic, scenic, cultural and open space values... and significance of the property, and have the common purpose of conserving the aforesaid conservation values of the Property in perpetuity..." It also outlined a process by which the County will have first refusal should the Friends decide to dispose of their interests altogether. In return for entering into this milestone agreement, the Friends received a payment of $\$ 390,000$ which will help to fund repairs and maintenance for some time. ${ }^{66}$ In looking ahead, the original goals of the Friends of the Old Yellow Meeting House remain unchanged - the preservation, care and appropriate use of a unique and important early historic landmark. To help achieve these key goals, the professional preparation of a long-needed Historic Structure Report

\footnotetext{
${ }^{66}$ Conservation Deed of Easement and Right of First Refusal Option Agreement between the Friends of the Old Yellow Meeting House and the County of Monmouth, 13 November 2019, recorded in Deed Book 9382, page 5594, Office of the Monmouth County Clerk, Freehold, NJ.
} 
with Preservation Plan elements included should also become a priority. This essay will constitute an important chapter in that lengthy and detailed document.

Joseph W. Hammond writes on New Jersey history topics from his retirement home in northern New Hampshire. His interests include decorative and fine arts, architecture, and social history. A resident of Freehold for more than forty years, he has in the past served the Monmouth County Historical Association as Director, Consulting Archivist, Curator of Museum Collections, and Director of Collections. He has also been engaged as a Consulting Architectural Historian for special projects by Westfield Architects \& Preservation Consultants of Haddon Heights, NJ. Hammond holds a B. A. degree in American History \& Civilization from Boston University, and an M. A. degree in History Museum Studies from the Cooperstown Program of the State University of New York, College at Oneonta. 